\title{
Synthesis and Characterization of Ruthenium Bis( $\beta$-diketonato) Pyridine-Imidazole Complexes for Hydrogen Atom Transfer
}

\author{
Adam Wu, Joshua Masland, Rodney D. Swartz ${ }^{\dagger}$, Werner Kaminsky ${ }^{\dagger}$, and James M. Mayer ${ }^{*}$ \\ Department of Chemistry, University of Washington, Campus Box 351700, Seattle, WA, \\ 98195-1700, USA
}

\section{Abstract}

Ruthenium bis( $\beta$-diketonato) complexes have been prepared at both the $\mathrm{Ru}^{\mathrm{II}}$ and $\mathrm{Ru} \mathrm{u}^{\mathrm{III}}$ oxidation levels and with protonated and deprotonated pyridine-imidazole ligands. $\mathrm{Ru}^{\mathrm{II}}(\mathrm{acac})_{2}(\mathrm{py}-\mathrm{imH})(\mathbf{1})$, $\left[\mathrm{Ru}^{\mathrm{III}}(\mathrm{acac})_{2}\left(\right.\right.$ py-imH)]OTf (2), Ru${ }^{\mathrm{III}}(\text { acac })_{2}\left(\right.$ py-im) (3), $\mathrm{Ru}^{\mathrm{II}}(\mathrm{hfac})_{2}($ py-imH) (4), and [DBU-H] $\left[\mathrm{Ru}^{\mathrm{II}}(\mathrm{hfac})_{2}(\mathrm{py}-\mathrm{im})\right](5)$ have been fully characterized, including X-ray crystal structures (acac $=$ 2,4-pentanedionato, $\mathrm{hfac}=1,1,1,5,5,5$-hexafluoro-2,4-pentanedionato, py-imH $=2$-(2'-pyridyl) imidazole, DBU $=1,8$-diazabicyclo[5.4.0]undec-7-ene). For the acac-imidazole complexes 1 and 2 , cyclic voltammetry in $\mathrm{MeCN}$ shows the $\mathrm{Ru}{ }^{\mathrm{III} / \mathrm{II}}$ reduction potential $\left(E_{1 / 2}\right)$ to be $-0.64 \mathrm{~V} v s$. $\mathrm{Cp}_{2} \mathrm{Fe}^{+/ 0} . E_{1 / 2}$ for the deprotonated imidazolate complex $3(-1.00 \mathrm{~V})$ is $0.36 \mathrm{~V}$ more negative. The $\mathrm{Ru}^{\mathrm{II}}$ bis-hfac analogs 4 and $\mathbf{5}$ show the same $\Delta E_{1 / 2}=0.36 \mathrm{~V}$ but are $0.93 \mathrm{~V}$ harder to oxidize than the acac derivatives $(0.29 \mathrm{~V}$ and $-0.07 \mathrm{~V})$. The difference in acidity between the acac and hfac derivatives is much smaller, with $\mathrm{p} K_{\mathrm{a}}$ values of 22.1 and 19.3 in MeCN for $\mathbf{1}$ and $\mathbf{4}$. From the $E_{1 / 2}$ and $\mathrm{p} K_{\mathrm{a}}$ values, the bond dissociation free energies (BDFEs) of the $\mathrm{N}-\mathrm{H}$ bonds in $\mathbf{1}$ and $\mathbf{4}$ are calculated to be 62.0 and $79.6 \mathrm{kcal} \mathrm{mol}^{-1}$ in MeCN - a remarkable difference of $17.6 \mathrm{kcal} \mathrm{mol}^{-1}$ for such structurally similar compounds. Consistent with these values, there is facile net hydrogen atom transfer from 1 to TEMPO ${ }^{*}$ (2,2,6,6-tetramethylpiperidine-1-oxyl radical) to give $\mathbf{3}$ and TEMPO-H. The $\Delta G^{\circ}$ for this reaction is $-4.5 \mathrm{kcal} \mathrm{mol}^{-1}$. Complex 4 is not oxidized by TEMPO $\left(\Delta G^{\circ}=+13.1\right.$ $\left.\mathrm{kcal} \mathrm{mol}^{-1}\right)$, but in the reverse direction TEMPO-H readily reduces in situ generated $\mathrm{Ru}^{\mathrm{III}}(\mathrm{hfac})_{2}$ (py-im) (6). A Ru${ }^{\mathrm{II}}$-imidazoline analog of $\mathbf{1}, \mathrm{Ru}^{\mathrm{II}}(\mathrm{acac})_{2}$ (py-imnH) (7), reacts with 3 equiv of TEMPO' to give the imidazolate complex 3 and TEMPO-H, with dehydrogenation of the imidazoline ring.

\section{Introduction}

Proton-coupled electron transfer (PCET) is a fundamental process in chemistry and biology. 1,2 Hydrogen atom transfer (HAT) reactions are one class of PCET processes, in which a hydrogen atom $\left(\mathrm{H}^{\cdot}=\mathrm{H}^{+}+e^{-}\right)$concertedly transfers from one reagent to another in a single kinetic step. HAT reactions of transition metal species are receiving much attention because of their role in metal-catalyzed oxidations, ranging from metal-oxide surfaces to various metalloenzymes. ${ }^{3}$ To cite just one example, the peroxidation of polyunsaturated fatty acids is catalyzed by lipoxygenases using HAT from the substrate to the active site $\mathrm{Fe}^{\mathrm{III}} \mathrm{OH}$ center forming the $\mathrm{Fe}^{\mathrm{II}} \mathrm{OH}_{2}$ moiety and the substrate pentadienyl radical. ${ }^{4}$ As this example illustrates, many metal-mediated HAT reactions involve redox change at the metal, coupled to a change in protonation state of the ligand. ${ }^{1-3,5}$ These systems can be described by the 'square scheme' in Scheme 1, with electron transfer (ET) and proton transfer (PT) reactions as the edges and HAT as the diagonal. ${ }^{2}$

* To whom correspondence should be addressed. E-mail: mayer@chem.washington.edu.

$\dagger$ UW Chemistry crystallographic facility. 
Our group has been building an understanding of metal-mediated HAT reactions by developing chemical systems in which both the thermodynamics and kinetics of HAT can be determined. Isolation of at least three corners of the square greatly facilitates these measurements. Among the systems we have studied, iron-tris(biimidazoline) complexes have been particularly informative in part because the $\mathrm{Fe}^{\mathrm{II}}$-protonated, $\mathrm{Fe}^{\mathrm{III}}$-protonated, and $\mathrm{Fe}^{\mathrm{III}}$-deprotonated complexes are all readily isolated. ${ }^{6}$ We have examined in detail the thermochemistry of this system, including its large entropy for HAT reactions, oxidations of C-H and $\mathrm{O}-\mathrm{H}$ bonds, rate constants for cross and self-exchange rates, and the agreement with the Marcus cross relation. 6a,b,7

A ruthenium system is of interest to test the generality of our HAT conclusions and to explore the analogies between HAT and ET. Electron transfer processes of Ru complexes have been studied in great detail, ${ }^{8}$ in part because the substitution-inert nature of low-spin $\mathrm{Ru}^{\mathrm{II}}$ complexes provides valuable stability and synthetic flexibility. The groups of Hammarström, ${ }^{9}$ Kramer, 10 and Nocera ${ }^{11}$ have each developed elegant ruthenium-polypyridyl systems for PCET studies. These systems involve stable $\mathrm{Ru}^{\mathrm{II}}$ complexes and photolytic generation of the corresponding $\mathrm{Ru}^{\mathrm{III}}$ complexes. While photolytic initiation of reactions is of great value for certain measurements, these systems are also limited by difficulties in isolating the $\mathrm{Ru}^{\mathrm{III}}$ species due to their high reduction potentials.

Our design criteria for a ruthenium PCET system were (i) suitable one-electron reduction potentials so that both $\mathrm{Ru}^{\mathrm{II}}$ and $\mathrm{Ru} \mathrm{u}^{\mathrm{III}}$ species could be isolated and (ii) the ability to prepare protonated and mono-deprotonated derivatives. After some initial efforts which are described below, we have developed a system with acac (2,4-pentanedionato) and 2-(2'-pyridyl) imidazole (py-imH) ligands, such as $\mathrm{Ru}^{\mathrm{II}}(\mathrm{acac})_{2}(\mathrm{py}-\mathrm{imH})(\mathbf{1})$, in which three corners of the square have been isolated. Py-imH is a well-known chelating ligand with a single ionizable proton, ${ }^{12,13}$ and stable $\mathrm{Ru}^{\mathrm{II}} / \mathrm{Ru}^{\mathrm{III}}$ pairs with two acac ligands have been reported, including cis-Ru ${ }^{\mathrm{II}}(\mathrm{acac})_{2}(\mathrm{MeCN})_{2} /$ cis- $\left[\mathrm{Ru}^{\mathrm{III}}(\mathrm{acac})_{2}(\mathrm{MeCN})_{2}\right] \mathrm{OTf}{ }^{14,15}$ and $\mathrm{Ru}^{\mathrm{II}}(\mathrm{acac})_{2}($ bpy $) /$ $\left[\mathrm{Ru}^{\mathrm{III}}(\mathrm{acac})_{2}\right.$ (bpy) $]-\mathrm{OTf}^{16}$ (bpy $=2,2^{\prime}$-bipyridine; OTf ${ }^{-}=$triflate, $\mathrm{CF}_{3} \mathrm{SO}_{3}{ }^{-}$). The related pyridine-imidazole complexes with hexafluoro-acac $(1,1,1,5,5,5$-hexafluoro- 2,4 pentanedionato, hfac) ligand have also been prepared in this work. Described here are the syntheses and characterization of the compounds that comprise new ruthenium PCET systems, together with thermochemical measurements and preliminary studies of their HAT reactions.

\section{Results}

\section{Syntheses}

Attempts to develop a ruthenium system analogous to the iron-tris(biimidazoline) complexes started with the known tris(bibenzimidazole) complex $\left[\mathrm{Ru}{ }^{\mathrm{II}}\left(\mathrm{H}_{2} \text { bibzim }\right)_{3}\right]\left(\mathrm{ClO}_{4}\right)_{2}\left(\mathrm{H}_{2}\right.$ bibzim $=2,2^{\prime}$-bibenzimidazole $) .{ }^{17}$ Unlike the iron system, $\left[\mathrm{Ru}{ }^{\mathrm{II}}\left(\mathrm{H}_{2} \text { bibzim }\right)_{3}\right]\left(\mathrm{ClO}_{4}\right)_{2}$ appears to doubly deprotonate upon titration with base, which made the study of HAT reactions problematic. ${ }^{18}$ To circumvent this issue, $\left[\mathrm{Ru}^{\mathrm{II}}(\mathrm{bpy})_{2}\left(2-\left(2^{\prime}\right.\right.\right.$-pyridyl)-benzimidazole $\left.)\right]\left(\mathrm{ClO}_{4}\right)_{2}$, which contains only one protonation site, was synthesized. ${ }^{13}$ However, this complex has a high $\mathrm{Ru}^{\mathrm{III} / \mathrm{II}}$ reduction potential $\left(E_{1 / 2}=0.86 \mathrm{~V}\right.$ vs. $\mathrm{Cp}_{2} \mathrm{Fe}^{+/ 0}$ in $\left.\mathrm{MeCN}{ }^{19}\right)$ and in our hands isolation of the $\mathrm{Ru}^{\mathrm{III}}$ derivative was not possible. 18

Following these initial efforts, we turned our attention to Ru(acac $)_{2}$ complexes of 2 -(2'-pyridyl) imidazole (py-imH) and 2-(2'-pyridyl)imidazoline (py-imnH). The latter complexes have more complex HAT chemistry, as described below, so we start here with the aromatic py-imH compounds. Treatment of $c i s-\mathrm{Ru}^{\mathrm{II}}(\mathrm{acac})_{2}(\mathrm{MeCN})_{2}{ }^{14}$ with 1.2 equiv of py-imH ${ }^{12}$ in $_{6} \mathrm{H}_{6}$ for $5 \mathrm{~h}$ at $80{ }^{\circ} \mathrm{C}$ under $\mathrm{N}_{2}$ forms $\mathrm{Ru}^{\mathrm{II}}(\mathrm{acac})_{2}$ (py-imH) (1) as a light brown precipitate, which was isolated by filtration in $78 \%$ yield (eq 1). Complex $\mathbf{1}$ is very air-sensitive in solution, but less so 


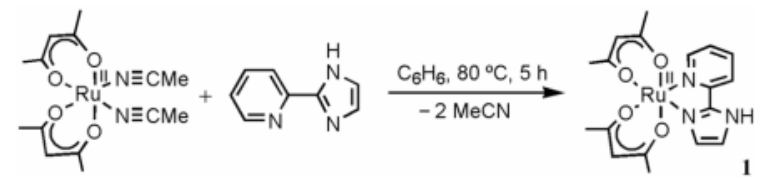

(1).

in the solid state. The $\mathrm{Ru}^{\mathrm{III}}$ analog $\left[\mathrm{Ru}^{\mathrm{III}}(\mathrm{acac})_{2}(\right.$ py-imH) $] \mathrm{OTf}(\mathbf{2})$ was prepared similarly by reacting $c$ is-[Ru $\left.{ }^{\mathrm{III}}(\mathrm{acac})_{2}(\mathrm{MeCN})_{2}\right] \mathrm{OTf} 15$ with 1.2 equiv of py-imH to give a brick-red solid in $74 \%$ yield (eq 2). The deprotonated $\mathrm{Ru}^{\mathrm{III}}$ derivative $\mathrm{Ru}^{\mathrm{III}}(\text { acac })_{2}$ (py-im) (3) is most easily

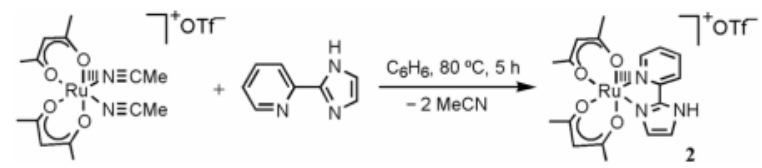

(2).

prepared by removal of a hydrogen atom from 1, using 1.2 equiv of TEMPO in $\mathrm{MeCN}$ at room temperature for $10 \mathrm{~min}$ (eq 3 ). The TEMPO-H byproduct is removed by sublimation, and $\mathbf{3}$ is

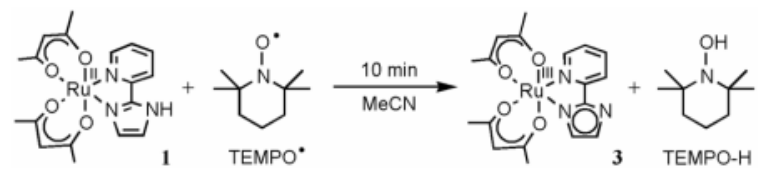

(3).

isolated as a dark brown solid in 65\% yield. Complex $\mathbf{3}$ can also be generated by reaction of 2 with 1 equiv of the base DBU (1,8-diazabicyclo[5.4.0]undec-7-ene) in MeCN (eq 4), but this is less convenient for preparative scale reactions. Addition of HOTf re-protonates $\mathbf{3}$ to form 2 (eq 4).

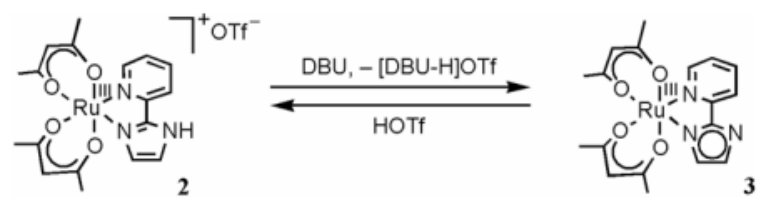

(4).

Related $\mathrm{Ru}^{\mathrm{II}}$-hexafluoro-acac derivatives are accessible starting from cis-

$\mathrm{Ru}^{\mathrm{II}}(\mathrm{hfac})_{2}(\mathrm{MeCN})_{2} .{ }^{15}$ Refluxing this compound with 1.7 equiv of py-imH in $\mathrm{C}_{6} \mathrm{H}_{6}$ for $16 \mathrm{~h}$ yields $\mathrm{Ru}^{\mathrm{II}}(\mathrm{hfac})_{2}$ (py-imH) (4), analogous to eq 1 . Red-brown $\mathbf{4}$ was obtained in $27 \%$ yield after silica gel chromatography. Unreacted $c i s-\mathrm{Ru}^{\mathrm{II}}(\mathrm{hfac})_{2}(\mathrm{MeCN})_{2}(21 \%)$ was also eluted from the column, but extending the reaction time or increasing the amount of py-imH (up to 10 equiv) did not improve the yield of 4 . Addition of 1 equiv of DBU immediately deprotonates 4 in $\mathrm{MeCN}$ to generate [DBU-H][Ru ${ }^{\mathrm{II}}(\mathrm{hfac})_{2}$ (py-im)] (5), which was isolated as a black-purple solid in 76\% yield (eq 5). Spectroscopic and X-ray characterizations of these compounds are presented in the next sections, and all the structures and compound numbers are shown in Scheme 2 below.

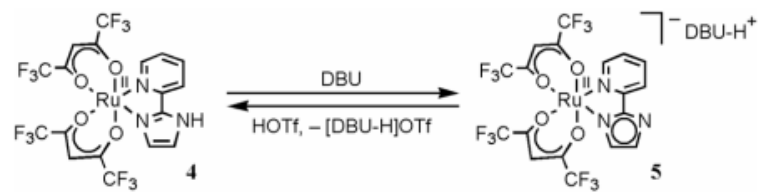


(5).

\section{X-ray Structures}

X-ray crystal structures of complexes 1-5 have been solved. ORTEP drawings of each ruthenium complex (with 50\% probability ellipsoids) are shown in Figures 1 and 2, and the crystallographic and metrical data are given in Tables 1 and 2 . The ruthenium complexes all have very similar distorted octahedral geometries, with trans angles $>170^{\circ}$. The py-imH ligands form five-membered chelate rings with small bite angles of 78.4(3)-79.6(3) ${ }^{\circ}$. The $\mathrm{Ru}-\mathrm{O}$ bond lengths are all quite similar for the three $\mathrm{Ru}^{\mathrm{II}}$ complexes 1, 4, and 5 (2.026(7)2.056(6) $\AA$ ) independent of whether the ligand is acac or hfac. The oxidized compounds $\mathbf{2}$ and 3 have slightly shorter Ru-O distances, 1.995(4)-2.017(4) $\AA$. These values are typical of related compounds. ${ }^{20,21}$ In $\mathbf{1}$, the $\mathrm{Ru}^{\mathrm{II}}-\mathrm{N}$ (imidazole) bond is 0.029(10) $\AA$ longer than the $\mathrm{Ru}^{\mathrm{II}}-\mathrm{N}(\mathrm{py})$ bond, but this is reversed in the $\mathrm{Ru}^{\mathrm{III}}$ complexes $\mathbf{2}$ and $\mathbf{3}$, where the bonds to the imidazole or imidazolate are 0.036(7) and 0.045(9) $\AA$ shorter. This presumably reflects the greater $\pi$ backbonding for $\mathrm{Ru}^{\mathrm{II}} \rightarrow$ py. This is also evident with the more electron-deficient hfac complex 4, which has less $\pi$-backbonding and thus has similar $\mathrm{Ru}-\mathrm{N}(\mathrm{py})$ and $\mathrm{Ru}-\mathrm{N}$ (imidazole) distances. Deprotonation of the imidazole ligand shortens its bond to $\mathrm{Ru}$, in both $\mathbf{3}$ and $\mathbf{5}$, as is typical for transition metal imidazole complexes. ${ }^{22}$ The imidazole ligands of $\mathbf{1}, \mathbf{2}, \mathbf{4}$, and $\mathbf{5}$ engage in various hydrogen bonding interactions in the crystals. In $\mathbf{1}$ and $\mathbf{4}$, there are intermolecular hydrogen bonds between imidazole N3-H and acac-oxygens $\left(d_{\mathrm{N}-\mathrm{O}}=2.806-\right.$ $2.913 \AA)$ while in 2 , the imidazole N3-H bonds with the OTf OT $^{-}$counter ion $\left(d_{\mathrm{N}-\mathrm{O}}=2.747 \AA\right)$. The deprotonated imidazolate $\mathrm{N} 3$ in $\mathbf{5}$ hydrogen bonds the acidic proton of DBU- $\mathrm{H}^{+}$with $d_{\mathrm{N}-\mathrm{N}}=2.746 \AA$. These hydrogen bonding distances are within the typical ranges: $2.5-3.2 \AA$. 23

\section{Spectroscopic Characterization}

The ${ }^{1} \mathrm{H}$ NMR spectra of $\mathbf{1 - 5}$ in $\mathrm{CD}_{3} \mathrm{CN}$ are consistent with the solid state structures. For instance, the spectrum of diamagnetic 1 shows two inequivalent acac ligands $\left[\delta\left(\mathrm{CH}_{3}\right) 2.05\right.$, 2.00 , and $\left.1.51\left(2 \mathrm{CH}_{3}\right) ; \delta(\mathrm{CH}) 5.32,5.29\right]$, six pyridine-imidazole- $\mathrm{CH}$ signals $(\delta 7.09-8.75)$, and an imidazole-NH peak at $\delta 11.31$ (which was confirmed by exchange with $\mathrm{CD}_{3} \mathrm{OD}$ ). The $\mathrm{Ru}^{\mathrm{II}}$ bis-hfac complexes $\mathbf{4}$ and $\mathbf{5}$ show similar proton resonances except for the absence of $\mathrm{CH}_{3}$ peaks and a N-H signal for $\mathbf{5}$. The ${ }^{19} \mathrm{~F}$ NMR spectra of $\mathbf{4}$ and $\mathbf{5}$ show four singlets between $\delta-74.74$ and -75.06 (referenced to $\mathrm{CF}_{3} \mathrm{C}(\mathrm{O}) \mathrm{OH}$ at $\delta-78.50$ ), ${ }^{24}$ consistent with the four inequivalent $\mathrm{CF}_{3}$ groups. The ${ }^{13} \mathrm{C}\left\{{ }^{1} \mathrm{H}\right\}$ NMR spectra of $\mathbf{4}$ and $\mathbf{5}$ in $\mathrm{CD}_{3} \mathrm{OD}^{25}$ show resonances for pyridine-imidazole $(\delta 118-168)$ and hfac-CH $(\delta 92-94)$, and four quartets for each of hfac$\mathrm{CF}_{3}\left(\delta 117-120,{ }^{1} J_{\mathrm{CF}}=282 \mathrm{~Hz}\right)$ and hfac-C $(\mathrm{O})\left(\delta 165-173,{ }^{2} J_{\mathrm{CF}}=33 \mathrm{~Hz}\right)$, again consistent with molecular $C_{1}$ symmetry.

The ${ }^{1} \mathrm{H}$ NMR spectra of paramagnetic complexes $\mathbf{2}$ and $\mathbf{3}$ (low-spin $\mathrm{d}^{5}$ ) in $\mathrm{CD}_{3} \mathrm{CN}$ span a wide range, from $\delta 6$ to -65 for 2 and $\delta 9$ to -48 for 3 (Figure 3). The four acac-methyl resonances for $\mathbf{2}(\delta-22$ to -17$)$ and $\mathbf{3}(\delta-18$ to -5$)$ are assigned based on integration. The imidazole-NH signal of 2 at $\delta 5.71$ was identified by its exchange with added $\mathrm{CD}_{3} \mathrm{OD} .{ }^{1} \mathrm{H} 2 \mathrm{D}$ COSY NMR spectra (Figure S1 for $\mathbf{2}$ and Figure S2 for $\mathbf{3}$ ), which have previously been useful for paramagnetic assignments, ${ }^{26}$ show cross peaks for three of the four pyridine resonances in each spectrum of $\mathbf{2}$ and $\mathbf{3}$ (peak 1 couples to peaks 2 and 3 in Figure 3). The other couplings were not observed, likely due to the paramagnetic broadening which lowers the signal intensity and renders even the COSY diagonal peaks unobservable. The fourth pyridine resonances are tentatively assigned based on their proximity in chemical shift with the other three pyridine signals, but the other signals for $\mathbf{2}$ and $\mathbf{3}$ could not be assigned.

The correspondences between the resonances of $\mathbf{2}$ and $\mathbf{3}$ are shown by ${ }^{1} \mathrm{H}$ NMR titration in $\mathrm{CD}_{3} \mathrm{CN}$. The addition of 1 equiv of $\operatorname{HOTf}\left(\mathrm{p} K_{\mathrm{a}}=2.60\right)^{27}$ in 0.1 equiv increments to a solution 
of $\mathbf{3}$ gradually changes the spectrum of $\mathbf{3}$ into that of $\mathbf{2}$, with the growth of the imidazole-NH signal ( $\delta$ 5.71). Complex 2 can be reversibly titrated back to 3 with 1 equiv of DBU ( $\mathrm{p} K_{\mathrm{a}}$ (DBU$\left.\mathrm{H}^{+}\right)=24.32^{28}$ ). Proton exchange between $\mathbf{2}$ and $\mathbf{3}$ is thus fast on the NMR timescale, so that solutions containing both complexes show an averaged spectrum. This and related selfexchange reactions will be discussed in a future publication. ${ }^{29}$

UV-vis spectra of $\mathbf{1}, \mathbf{4}$, and $\mathbf{5}$ all show strong MLCT bands in the visible region $(\varepsilon=6700$ $11000 \mathrm{M}^{-1} \mathrm{~cm}^{-1}$, Figure 4), as is typical of $\mathrm{Ru}^{\mathrm{II}}$-pyridyl complexes. ${ }^{16,20 \mathrm{~b}, 30,31}$ As expected, the trend in the lowest MLCT energies, $\mathbf{1}<\mathbf{5}<\mathbf{4}$, follows the ease of oxidation (see below). However, the energies for $\mathbf{1}$ and $\mathbf{5}$ are quite close despite their $0.57 \mathrm{~V}$ difference in reduction potentials, and the two MLCT bands for $\mathbf{1}$ are much more widely spaced than those for the hfac analog 4 . The $\mathrm{Ru}^{\mathrm{III}}$ complexes $\mathbf{2}$ and $\mathbf{3}$ have much weaker charge transfer transitions $(\varepsilon=$ $2000,1600 \mathrm{M}^{-1} \mathrm{~cm}^{-1}$ ).

Electron impact mass spectra (EI/MS) of 1, 2, and $\mathbf{3}$ are indistinguishable in the positive ion mode, each showing a mass cluster peaked at $444 \mathrm{~m} / \mathrm{z}$ which matches the simulated isotopic pattern for $\left[\mathrm{Ru}(\mathrm{acac})_{2} \text { (py-im) }\right]^{+}$. Thus $\mathbf{1}$ and $\mathbf{2}$ are deprotonated in the process of obtaining EI/ MS, and $\mathbf{1}$ is oxidized. With electrospray ionization (ESI) in MeCN, 2 and $\mathbf{3}$ show the protonated ion $\left[\mathrm{Ru}(\mathrm{acac})_{2}(\mathrm{py}-\mathrm{imH})\right]^{+}$, centered at $445 \mathrm{~m} / z$. (The air-sensitivity of 1 precludes its analysis by ESI/MS.) Positive ion ESI/MS of $\mathbf{4}$ and $\mathbf{5}$ similarly show an isotopic pattern which matches the oxidized, protonated species, $\left[\mathrm{Ru}(\mathrm{hfac})_{2}(\mathrm{py}-\mathrm{imH})\right]^{+}(661 \mathrm{~m} / \mathrm{z})$. Complex 5 also shows, in the negative ion ESI/MS, a cluster at $660 \mathrm{~m} / z$ for the parent anion, $[\mathrm{Ru}$ $(\text { hfac })_{2}(\text { py-im) }]^{-}$.

\section{Thermochemical Measurements}

(i) Cyclic Voltammetry-Cyclic voltammograms (CVs) of 1-5 in MeCN all show chemically reversible waves. In each case, the anodic and cathodic currents $\left(i_{\mathrm{a}}\right.$ and $\left.i_{\mathrm{c}}\right)$ are equal within $10 \%$. The peak separations $\left(E_{\mathrm{p}, \mathrm{a}}-E_{\mathrm{p}, \mathrm{c}}\right)$ at a scan rate of $100 \mathrm{mV} \mathrm{s}^{-1}$ are close to those of ferrocene in the same solution $(80-100 \mathrm{mV})$, but at higher scan rates the Ru complexes show larger separations (up to $40 \mathrm{mV}$ larger). The waves correspond to the $\mathrm{Ru} \mathrm{u}^{\mathrm{III} / \mathrm{II}}$ redox couples. $E_{1 / 2}$ for $\mathbf{1}$ and $\mathbf{2}$ is at $-0.64 \mathrm{~V}$, which shifts to $-1.00 \mathrm{~V}$ upon deprotonation to form $\mathbf{3}$ (potentials $\pm 0.01 \mathrm{~V}$ in $\mathrm{MeCN}$ referenced to internal $\mathrm{Cp}_{2} \mathrm{Fe}^{+/ 0}$ ). The hfac compounds are $0.93 \mathrm{~V}$ more difficult to oxidize: $E_{1 / 2}=0.29 \mathrm{~V}(\mathbf{4})$ and $-0.07 \mathrm{~V}(\mathbf{5})$. In both the acac and hfac compounds, the protonated form $(\mathbf{1}, \mathbf{2}$ or $\mathbf{4})$ has a higher reduction potential than the deprotonated species (3 or $\mathbf{5})$ by $0.36 \mathrm{~V}$.

(ii) $\mathbf{p} K_{\mathrm{a}}$ Values-The interconversion of protonated $\mathbf{2}$ and deprotonated $\mathbf{3}$ in $\mathrm{MeCN}$ by 1 equiv of DBU or HOTf (eq 4 above) was monitored by optical spectroscopy, confirming the ${ }^{1} \mathrm{H}$ NMR results described above. Titration of $\mathbf{2}$ with an excess of the weak base 2,4-lutidine $\left(\mathrm{p} K_{\mathrm{a}}\left(2,4 \text {-lutidine- } \mathrm{H}^{+}\right)=14.05\right)^{27}$ forms $\mathbf{3}$ in an equilibrium. With concentrations of $\mathbf{2}$ and $\mathbf{3}$ determined from optical spectra (Figure 4), the equilibrium constant for $2+2,4$-lutidine $\rightleftarrows$ $3+(2,4$-lutidine-H)OTf was determined to be $0.011 \pm 0.001$ from the slope of the linear plot: $[3]\left[2,4-\right.$ lutidine- $\left.\mathrm{H}^{+}\right] /[2]$ vs. [2,4-lutidine] (Figure $\mathrm{S} 3$ and Experimental). This $K_{\mathrm{eq}}$ and the $\mathrm{p} K_{\mathrm{a}}$ of 2,4-lutidine- $\mathrm{H}^{+}$give $\mathrm{p} K_{\mathrm{a}}(\mathbf{2})=16.0 \pm 0.1$. Similarly, $\mathrm{UV}$-vis monitoring shows quantitative interconversion of the $\mathrm{Ru}^{\mathrm{II}}$ hfac derivatives $\mathbf{4}$ and $\mathbf{5}$ with DBU and HOTf (eq 5). Titration of 4 with $\mathrm{Et}_{3} \mathrm{~N}\left(\mathrm{p} K_{\mathrm{a}}\left(\mathrm{Et}_{3} \mathrm{NH}^{+}\right)=18.46\right)^{27}$ gives a $\mathrm{p} K_{\mathrm{a}}$ of $19.3 \pm 0.1$ for 4 .

\section{Hydrogen Atom Transfer Reactions of the Imidazole/Imidazolate Complexes with TEMPO\% TEMPO-H}

Complex 1 in $\mathrm{CD}_{3} \mathrm{CN}$ is rapidly oxidized by 1 equiv of TEMPO at ambient temperatures to produce 3 and TEMPO- $\mathrm{H}^{32}$ (eq 3 above). This reaction has been monitored by optical and ${ }^{1} \mathrm{H}$ NMR spectroscopies, and is evident by the solution color changing from the red-purple 
of $\mathbf{1}$ to the pale-brown of $\mathbf{3}$. This and related hydrogen atom transfer (HAT) reactions in the $\mathrm{Ru}(\mathrm{acac})_{2}$ system will be described in detail in a future publication, including HAT selfexchange reactions and kinetic isotope effects. 29

The hfac analog 4, however, does not react with 36 equiv of TEMPO in $\mathrm{CD}_{3} \mathrm{CN}$ at room temperature under $\mathrm{N}_{2}$ after $1 \mathrm{~d}$ (eq 6). To understand this lack of reactivity, the expected

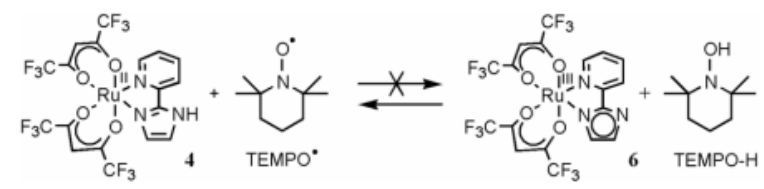

(6).

product, $\mathrm{Ru}^{\mathrm{III}}(\mathrm{hfac})_{2}$ (py-im) (6), was generated in situ by oxidation of 5 with 1 equiv of tri-ptolylaminium hexafluorophosphate $\left(\left[\mathrm{N}(\mathrm{tol})_{3}\right] \mathrm{PF}_{6}, E_{1 / 2}=0.38 \mathrm{~V} v \text { s. } \mathrm{Cp}_{2} \mathrm{Fe}^{+/ 0}\right)^{33}(\mathrm{eq} 7)$.

Monitoring

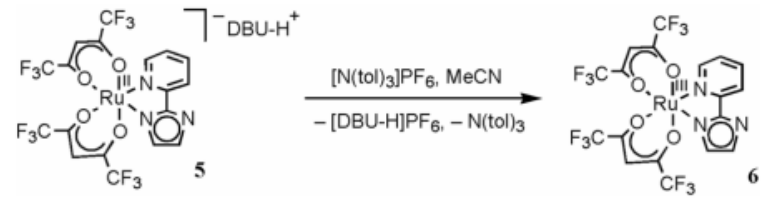

(7).

reaction 7 by UV-vis spectroscopy shows an isosbestic point at $450 \mathrm{~nm}$ up to 1 equiv of [N $\left.(\text { tol })_{3}\right] \mathrm{PF}_{6}$ (Figure S4). Beyond 1 equiv, the absorbance due to $\left[\mathrm{N}(\mathrm{tol})_{3}\right] \mathrm{PF}_{6}$ at $\lambda_{\max }=668 \mathrm{~nm}$ $\left(\varepsilon=26,200 \mathrm{M}^{-1} \mathrm{~cm}^{-1}\right)^{34}$ grows in. By ${ }^{1} \mathrm{H} \mathrm{NMR}$, addition of 1 equiv of $\left[\mathrm{N}(\mathrm{tol})_{3}\right] \mathrm{PF}_{6}$ in $\mathrm{CD}_{3} \mathrm{CN}$ causes disappearance of the resonances of 5 but no resonances for paramagnetic $\mathbf{6}$ are observed. The $\mathrm{CV}$ of this in situ generated $\mathbf{6}$ shows a reversible wave with $E_{1 / 2}=-0.07 \mathrm{~V}$, identical to that of 5. Complex $\mathbf{6}$ appears to slowly decay in solution, as small amounts of the $\mathrm{Ru}^{\mathrm{II}}$ protonated complex $\mathbf{4}$ are observed by NMR after $\sim 20 \mathrm{~min}$ at room temperature under $\mathrm{N}_{2}$. Attempts to isolate 6 by re-precipitation with $\mathrm{CH}_{2} \mathrm{Cl}_{2} / n$-pentane under $\mathrm{N}_{2}$ lead to the isolation of 4. In situ prepared 6 reacts rapidly with 1 equiv of TEMPO-H to quantitatively form 4 (eq 6), as monitored by ${ }^{1} \mathrm{H}$ NMR and UV-vis (Figure S4) spectroscopies. The lack of reaction of $\mathbf{4}$ with TEMPO ${ }^{*}$ thus has a thermochemical, rather than a kinetic origin (see below).

\section{Imidazoline Complexes and Their Reactions with TEMPO•}

Prior to studying the pyridine-imidazole complexes above, we explored complexes of the partially saturated analog, 2-(2'-pyridyl)imidazoline (py-imnH). ${ }^{35}$ Analogous to the procedures used for $\mathbf{1}$ and $\mathbf{4}, \mathrm{Ru}^{\mathrm{II}}(\mathrm{acac})_{2}(\mathrm{py}-\mathrm{imnH})(\mathbf{7})$ and $\mathrm{Ru}^{\mathrm{II}}(\mathrm{hfac})_{2}(\mathrm{py}$-imnH) $(\mathbf{8})$ were synthesized from the bis(acetonitrile) derivatives (eq 8).

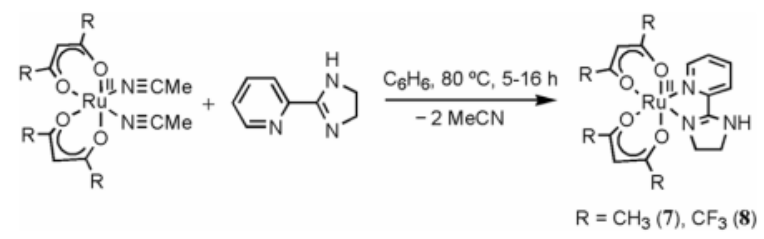

(8).

The X-ray structure of the hfac-imidazoline complex $\mathbf{8}$ (Figure 2c) is similar to that of the imidazole analog 4 , but the saturated imidazoline $\mathrm{C}-\mathrm{C}$ bond $(1.591(10) \AA)$ is longer than the imidazole $\mathrm{C}=\mathrm{C}$ bond (1.443(14) $\AA$ ). Complex 7 has a ${ }^{1} \mathrm{H}$ NMR spectrum analogous to that of 
1 except that the imidazoline $\mathrm{CH}_{2}$ multiplets ( $\delta$ 3.6-4.0) and $\mathrm{NH}$ singlet $(\delta 6.12)$ are shifted more upfield than the aromatic imidazole $\mathrm{CH}(\delta 7-8)$ and $\mathrm{NH}$ signals $(\delta 11.31)$, as expected. The hfac complexes 8 and $\mathbf{4}$ show the same pattern. The ${ }^{13} \mathrm{C}\left\{{ }^{1} \mathrm{H}\right\}$ NMR spectrum of 8 in $\mathrm{CD}_{3} \mathrm{OD}$ shows resonances similar to those of $\mathbf{4}$ and $\mathbf{5}$, except that the imidazoline $\mathrm{C}-\mathrm{H}$ peaks $(\delta 46.12,55.58)$ are more upfield than those of the imidazole $(\delta 121-133)$. Cyclic voltammetry of the imidazoline complexes gives $\mathrm{Ru}^{\mathrm{III} / \mathrm{II}} E_{1 / 2}$ values of $-0.68 \mathrm{~V}$ for $\mathbf{7}$ and $0.14 \mathrm{~V}$ for 8 . Complexes $\mathbf{7}$ and $\mathbf{8}$ are slightly easier to oxidize than their imidazole analogs $\mathbf{1}$ and $\mathbf{4}$, by 0.04 and $0.15 \mathrm{~V}$.

The $\mathrm{Ru}^{\mathrm{II}}$-acac-imidazoline complex 7 in $\mathrm{CD}_{3} \mathrm{CN}$ reacts slowly with 3 equiv of TEMPO` at room temperature under $\mathrm{N}_{2}$ to give the imidazolate complex 3 and TEMPO-H (eq 9), as

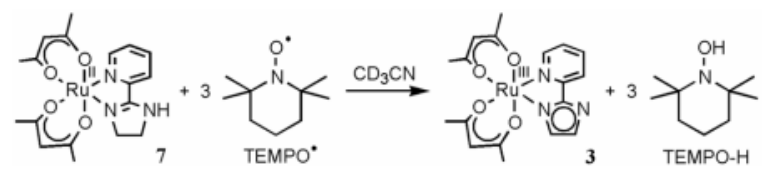

(9).

monitored by ${ }^{1} \mathrm{H}$ NMR. The formation of $\mathbf{3}$ involves removal of three hydrogen atoms from the imidazoline ring, one from the $\mathrm{NH}$ and one from each of the methylene groups. Such dehydrogenation of imidazoline has not been observed in any of the iron chemistry we have explored, $6 a, b, 7$ but oxidation of coordinated amines is well known for ruthenium complexes. 36 This dichotomy may be a result of the dehydrogenation requiring $\mathrm{M}^{\mathrm{IV}}$ intermediate(s) which are accessible for $\mathrm{Ru}^{\mathrm{IV}}$ but too high in energy for $\mathrm{Fe}^{\mathrm{IV} .36}$ Reaction 9 does not proceed quantitatively, but with 10 equiv of TEMPO ${ }^{\circ}$ a yield of $72 \%$ of 3 is observed by ${ }^{1} \mathrm{H}$ NMR after $1 \mathrm{~d}$. The hfac analog 8 also reacts slowly with 10 equiv of TEMPO in $\mathrm{CD}_{3} \mathrm{CN}$ at room temperature under $\mathrm{N}_{2}$ to aromatize the imidazoline ligand, but in this case the $\mathrm{Ru}^{\mathrm{II}}$ protonated complex 4 is formed in 50\% yield after $4 \mathrm{~d}$ (eq 10), with some starting 8 (14\%) still remaining.

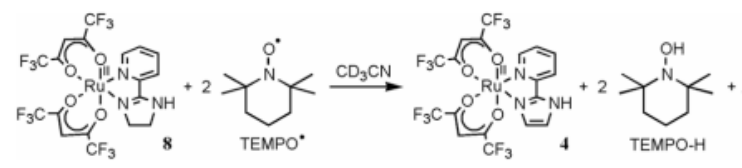

(10).

\section{Discussion}

\section{Bond Dissociation Free Energies (BDFEs) of 1 and 4}

The thermochemical data above can be assembled into 'square schemes' 2 that are thermochemical maps of the Ru acac-imidazole and hfac-imidazole systems (Scheme 2). The horizontal equilibrium arrows give the $\mathrm{p} K_{\mathrm{a}}$ values, the verticals give the $E_{1 / 2}$ potentials, and the diagonals are the bond dissociation free energies (BDFEs) for hydrogen atom transfer (HAT). BDFEs are derived from the $\mathrm{p} K_{\mathrm{a}}$ and $E_{1 / 2}$ values using eq 11 , where $\mathrm{R}$ is the gas constant, $\mathrm{T}$ is temperature, and $\mathrm{F}$ is the Faraday constant. ${ }^{37}$

$$
\begin{aligned}
& \mathrm{BDFE}=2.3 \mathrm{RTp} K_{\mathrm{a}}+\mathrm{F} E_{1 / 2}+C_{\mathrm{G}} \\
& =\left[1.37 \mathrm{p} K_{\mathrm{a}}+23.1 E_{1 / 2}+54.9\right] \mathrm{kcal} \mathrm{mol}^{-1}
\end{aligned}
$$

$C_{\mathrm{G}}$ is the free energy for $\mathrm{H}^{+}{ }_{\mathrm{MeCN}}+\mathrm{e}^{-} \rightarrow \mathrm{H}^{\cdot}{ }_{\mathrm{MeCN}}$. It has been given by Tilset ${ }^{37 \mathrm{a}}$ as the sum of $\mathrm{F}\left[E^{\circ}\left(\mathrm{Cp}_{2} \mathrm{Fe}^{+/ 0}\right)-E^{\circ}\left(\mathrm{H}^{+} / \mathrm{H}_{2}\right)\right]$ (equal to $\left.1.2 \mathrm{kcal} \mathrm{mol}^{-1}\right), 38$ the free energy of formation of $\mathrm{H} \bullet$ in the gas phase $\left[\Delta G^{\circ}\left(\mathrm{H}^{\circ}\right)_{\mathrm{g}}=48.6 \mathrm{kcal} \mathrm{mol}^{-1}\right],{ }^{39}$ and the free energy of solvation of $\mathrm{H} \bullet$ $\left(\Delta G_{\text {solv }}^{\circ}\left(\mathrm{H}^{\circ}\right)_{\mathrm{MeCN}}=5.1 \mathrm{kcal} \mathrm{mol}^{-1}\right) .{ }^{40}$ Thus $C_{\mathrm{G}}$ in $\mathrm{MeCN}$ with potentials referenced to 
$\mathrm{Cp}_{2} \mathrm{Fe}^{+/ 0}$ is equal to $54.9 \mathrm{kcal} \mathrm{mol}^{-1.37}$ Using eq 11 , this value of $C_{\mathrm{G}}$, the $\mathrm{p} K_{\mathrm{a}}$ of 2 and the $E_{1 / 2}$ for 3 give the BDFE of the N-H bond in $\mathbf{1}$ to be $62.0 \pm 1.0 \mathrm{kcal} \mathrm{mol}^{-1}$ in $\mathrm{MeCN}$ at 298 $\mathrm{K} .{ }^{41}$ Similarly, the BDFE of 4 is calculated to be $79.6 \pm 1.0 \mathrm{kcal} \mathrm{mol}^{-1}$, using the $\mathrm{p} K_{\mathrm{a}}$ of 4 and $E_{1 / 2}$ of $\mathbf{5}$.

The four outside edges of the square scheme also form a thermochemical cycle, so the sum of these four terms (in free energy terms) must equal to zero (eq 12). For both the acac and

$$
1.37\left[\mathrm{p} K_{\mathrm{a}}(\mathbf{1})-\mathrm{p} K_{\mathrm{a}}(\mathbf{2})\right]+23.1\left[E_{1 / 2}(\mathbf{3})-E_{1 / 2}(\mathbf{2})\right]=0
$$

hfac systems, two reduction potentials and one $\mathrm{p} K_{\mathrm{a}}$ have been measured, so eq 12 enables calculation of the second $\mathrm{p} K_{\mathrm{a}}: 22.1 \pm 0.3$ for $\mathbf{1}$ and $13.2 \pm 0.3$ for $\left[\mathrm{Ru}^{\mathrm{III}}(\mathrm{hfac})_{2}(\mathrm{py}-\mathrm{imH})\right]^{+}$.

\section{Thermochemistry and Reactivity}

The thermochemical measurements are consistent with the observed reactivity of the ruthenium complexes with TEMPO ${ }^{\bullet}$ and TEMPO-H. The O-H BDFE of TEMPO-H is $66.5 \pm 1.1 \mathrm{kcal}$ $\mathrm{mol}^{-1.7 \mathrm{~b}}$ The reaction of $\mathbf{1}$ plus TEMPO ${ }^{\circ}$ to give 3 and TEMPO-H therefore has $\Delta G^{\circ}{ }_{3}=-4.5$ $\pm 0.9 \mathrm{kcal} \mathrm{mol}^{-1}[=\operatorname{BDFE}(\mathbf{1})-\mathrm{BDFE}(\mathrm{TEMPO}-\mathrm{H})]^{42}$ and $K_{\mathrm{eq}} \cong 2 \times 10^{3}$. This agrees with the experimental observation that $1+$ TEMPO$^{*}$ proceeds to completion, as monitored by ${ }^{1} \mathrm{H}$ NMR (eq 3). The calculated free energy for the reaction of the hfac complex 4 with TEMPO' (eq 6) is strongly unfavorable, $\Delta G^{\circ}{ }_{6}=+13.1 \pm 0.9 \mathrm{kcal} \mathrm{mol}^{-1}$. This is consistent with the lack of observed reactivity in the forward direction, and the facile reaction in the opposite direction: $\mathbf{6}+$ TEMPO-H $\rightarrow \mathbf{4}+$ TEMPO .

The $\mathrm{Ru}^{\mathrm{II}}$ acac complexes $\mathbf{1}$ and $\mathbf{7}$ are air-sensitive because they are reducing and have relatively weak $\mathrm{N}-\mathrm{H}$ bonds. Stirring a solution of $\mathbf{1}$ in $\mathrm{MeCN}$ under air produces mainly the $\mathrm{Ru}^{\mathrm{III}}$ deprotonated complex $\mathbf{3}$. The mechanism of reaction of $\mathbf{1}$ with $\mathrm{O}_{2}$ could proceed by initial electron transfer to give 2 and $\mathrm{O}_{2}-\bullet\left(E=-0.46 \mathrm{~V}, \Delta G^{\circ}=+11 \mathrm{kcal} \mathrm{mol}^{-1}\right)$, by initial HAT to give $3+\mathrm{HO}_{2}{ }^{\bullet}\left(\Delta G^{\circ} \cong+2 \mathrm{kcal} \mathrm{mol}^{-1}\right),{ }^{43}$ or by chain or base-catalyzed processes. ${ }^{44}$ The overall reaction of $\mathbf{1}$ with $\mathrm{O}_{2}$ is favorable by roughly $18 \mathrm{kcal}$ per mole of ruthenium (Scheme 3). This is only an estimate because it uses the gas phase value for $1 / 4 \mathrm{O}_{2}+\mathrm{H}^{*} \rightarrow 1 / 2 \mathrm{H}_{2} \mathrm{O} ;{ }^{43}$ a proper analysis would use the value in MeCN solution. The hfac complexes $\mathbf{4}$ and $\mathbf{8}$, in contrast, are not air-sensitive at least in part because their reactions with $\mathrm{O}_{2}$ are significantly less favorable: $\Delta G^{\circ} \sim 0 \mathrm{kcal} \mathrm{mol}^{-1}$ for $\mathbf{4}+1 / 4 \mathrm{O}_{2} \rightarrow \mathbf{6}+1 / 2 \mathrm{H}_{2} \mathrm{O}$.

The $\mathrm{Ru}^{\mathrm{III}}$ hfac deprotonated complex 6 has eluded isolation because of its ease of reduction, while the acac analog $\mathbf{3}$ is quite stable. Complex $\mathbf{6}$ appears to decay at least in part due to reactions with trace impurities in the solvents used, despite various purification attempts. The sensitivity of $\mathbf{6}$ does not appear due to its reduction potential, which at $E_{1 / 2}=-0.07 \mathrm{~V} v s$. $\mathrm{Cp}_{2} \mathrm{Fe}^{+/ 0}$ is relatively modest, but rather seems to result from its ability to form a strong $\mathrm{N}-\mathrm{H}$ bond $\left(\mathrm{BDFE}=79.6 \mathrm{kcal} \mathrm{mol}^{-1}\right)$. We and others have been working with a variety of hydrogen atom abstractors, ${ }^{45}$ and as a general rule of thumb, it is often difficult to isolate species that add $\mathrm{H}^{\bullet}$ to form a bond with a BDFE above ca. $80 \mathrm{kcal} \mathrm{mol}^{-1}$. Converting this to the more commonly used bond dissociation enthalpy (BDE) ${ }^{7 \mathrm{~b}}$ the borderline is ca. $85 \mathrm{kcal} \mathrm{mol}^{-1}$. [For a given $\mathrm{X}-\mathrm{H}$ bond, the $\mathrm{BDE}$ in $\mathrm{MeCN}$ is roughly $4.6 \mathrm{kcal} \mathrm{mol}^{-1}$ larger than the BDFE, using the not-always-accurate assumption that $S^{\circ}(\mathrm{X})=S^{\circ}(\mathrm{XH}){ }^{7 \mathrm{~b}}$ ]

\section{Thermochemical Comparisons}

Replacing two acac ligands with less donating hfac ligands makes the metal less electron rich and raises the $\mathrm{Ru}^{\mathrm{III} / \mathrm{II}}$ reduction potential. The difference is $0.93 \mathrm{~V}$ for both the protonated (1, $\mathbf{2} v s . \mathbf{4})$ and deprotonated imidazole complexes $(\mathbf{3} v s . \mathbf{5})$, and $0.82 \mathrm{~V}$ for the protonated imidazoline complexes $(\mathbf{7} v \mathbf{~ 8})$. Similar differences in $E_{1 / 2}$ have been reported for related acac/ 
hfac pairs: $\Delta E_{1 / 2}=0.88 \mathrm{~V}^{16}$ for $\left[\mathrm{Ru}(\mathrm{hfac} / \mathrm{acac})_{2}(\mathrm{bpy})\right]^{+/ 0}$ and $0.99 \mathrm{~V}$ for cis-[Ru(hfac/ acac $\left.)_{2}(\mathrm{MeCN})_{2}\right]^{+/ 0.15,46}$ The Lever parameters ${ }^{47}$ predict a change of $E_{1 / 2}$ by $0.97 \mathrm{~V}$ between Ru bis-acac and bis-hfac complexes, in very good agreement with the observed $\Delta E_{1 / 2}$ for the bis-acetonitrile and imidazole complexes, but somewhat overestimating the change for the bpy and imidazoline species.

The acac complex 1 has a $17.6 \pm 0.4^{42} \mathrm{kcal} \mathrm{mol}^{-1}$ weaker $\mathrm{N}-\mathrm{H}$ bond than the hfac derivative 4. This is a dramatic difference in BDFEs. For comparison, replacing $\mathrm{CH}_{3}$ for $\mathrm{CF}_{3}$ in substituted toluenes, $p$ - $\mathrm{CH}_{3} \mathrm{C}_{6} \mathrm{H}_{4} \mathrm{CH}_{3}$ vs. $p-\mathrm{CF}_{3} \mathrm{C}_{6} \mathrm{H}_{4} \mathrm{CH}_{3}$, shifts the benzylic $\mathrm{C}-\mathrm{H}$ bond dissociation enthalpies (BDE) ${ }^{48}$ only by $0.9 \mathrm{kcal} \mathrm{mol}^{-1}$ (for organic compounds, $\triangle \mathrm{BDE} \cong \triangle \mathrm{BDFE}^{7 \mathrm{~b}}$ ). For anilines and phenols the differences are somewhat larger, for instance $\triangle \mathrm{BDE}=5.2 \mathrm{kcal}$ $\mathrm{mol}^{-1}$ for $p-\mathrm{CH}_{3} \mathrm{C}_{6} \mathrm{H}_{4} \mathrm{NH}-\mathrm{H} v$ s. $p-\mathrm{CF}_{3} \mathrm{C}_{6} \mathrm{H}_{4} \mathrm{NH}-\mathrm{H}{ }^{48}$ In general, changes that make a compound less electron rich will raise the reduction potential and lower the $\mathrm{p} K_{\mathrm{a}}$, changes that balance each other in terms of the BDFE (eq 11). Thus the BDFE (and BDE) are less sensitive to substituent effects than either the $E_{1 / 2}$ or $\mathrm{p} K_{\mathrm{a}}$. Electron or proton transfer involves changes in charge and charge distribution, while homolytic $\mathrm{X}-\mathrm{H}$ bond scission is to a first approximation a non-polar process. This has been beautifully illustrated by DuBois et al. for nickel and palladium hydride complexes. ${ }^{49}$ For $\left[\mathrm{Pd}(\mathrm{H})(\text { diphosphine })_{2}\right]^{+}$complexes, varying the ligands shifts the redox potentials by $0.30 \mathrm{~V}$ (equivalent to $7 \mathrm{kcal} \mathrm{mol}^{-1}$ ), while the $\mathrm{p} K_{\mathrm{a}}$ values shift by 4.7 units in the opposite direction, so that the BDFEs vary by only $0.7 \mathrm{kcal}$ $\mathrm{mol}^{-1}(\mathrm{Pd}) .{ }^{49 \mathrm{a}}$ In the related Ni system, the shift of $0.32 \mathrm{~V}$ in $E_{1 / 2}$ is more than offset by the $7 \mathrm{p} K_{\mathrm{a}}$ unit shift, so that the more basic compounds have higher BDFEs by $2.0 \mathrm{kcal} \mathrm{mol}^{-1.49 \mathrm{~b}}$

These examples illustrate that the $17.6 \pm 0.4 \mathrm{kcal} \mathrm{mol}^{-1}$ shift between acac and hfac ruthenium complexes described here is particularly large. It occurs because the reduction potentials are much more affected than the $\mathrm{p} K_{\mathrm{a}}$ values: the $\Delta E_{1 / 2}$ of $0.93 \mathrm{~V}$ corresponds to $\Delta \Delta G^{\circ}=21.4 \mathrm{kcal}$ $\mathrm{mol}^{-1}\left(=\mathrm{F} \Delta E_{1 / 2}\right)$ while the $\Delta \mathrm{p} K_{\mathrm{a}}$ of 2.8 units is only $\Delta \Delta G^{\circ}=3.8 \mathrm{kcal} \mathrm{mol}^{-1}\left(=2.3 \mathrm{RT} \Delta \mathrm{p} K_{\mathrm{a}}\right)$. While for toluene $\mathrm{C}-\mathrm{H}^{48}$ and $\left[\mathrm{HPd}(\text { diphosphine })_{2}\right]^{+} \mathrm{Pd}-\mathrm{H}^{49 \mathrm{a}}$ bond strengths, $\mathrm{F} \Delta E_{1 / 2}$ and $2.3 \mathrm{RT} \Delta \mathrm{p} K_{\mathrm{a}}$ are equal in magnitude, for the acac $v s$. hfac complexes $\mathrm{F} \Delta E_{1 / 2}$ is 5.6 times as large as $2.3 \mathrm{RT} \Delta \mathrm{p} K_{\mathrm{a}}$. The disconnection between $\Delta E_{1 / 2}$ and $\Delta \mathrm{p} K_{\mathrm{a}}$ may is likely due to the four $\mathrm{CF}_{3} / \mathrm{CH}_{3}$ groups being are six bonds removed from the $\mathrm{N}-\mathrm{H}$ bond, causing little effect on the loss of the proton, but only three bonds removed from the Ru center that at least formally loses the electron.

\section{Conclusions}

A ruthenium acac pyridine-imidazole system has been developed that is very well suited for the study of metal-mediated hydrogen atom transfer. Both the $\mathrm{Ru}^{\mathrm{II}}$ protonated and $\mathrm{Ru}$ III deprotonated complexes, $\mathrm{Ru}^{\mathrm{II}}(\mathrm{acac})_{2}(\mathrm{py}-\mathrm{imH})(\mathbf{1})$ and $\mathrm{Ru}^{\mathrm{III}}(\mathrm{acac})_{2}(\mathrm{py}-\mathrm{im})(\mathbf{3})$ have been isolated and well characterized, fulfilling our design criteria of suitable one-electron reduction potential couples between protonated and mono-deprotonated species for the $\mathrm{Ru}^{\mathrm{II}}$ and $\mathrm{Ru}^{\mathrm{III}}$ states. The reduction potential and $\mathrm{p} K_{\mathrm{a}}$ measurements indicate that the removal of a $\mathrm{H}^{\bullet}$ from the imidazole $\mathrm{N}-\mathrm{H}$ in 1 has a BDFE of $62.0 \mathrm{kcal} \mathrm{mol}^{-1}$ in $\mathrm{MeCN}$ at $298 \mathrm{~K}$, and $79.6 \mathrm{kcal}$ $\mathrm{mol}^{-1}$ in $\mathrm{Ru}^{\mathrm{II}}(\mathrm{hfac})_{2}(\mathrm{py}-\mathrm{imH})$ (4). The remarkable $17.6 \mathrm{kcal} \mathrm{mol}^{-1}$ difference in BDFEs is primarily due to an increase in $E_{1 / 2}\left(0.93 \mathrm{~V}, 21.4 \mathrm{kcal} \mathrm{mol}^{-1}\right)$ with small compensation from the decrease of $\mathrm{p} K_{\mathrm{a}}\left(2.8\right.$ units, $\left.3.8 \mathrm{kcal} \mathrm{mol}^{-1}\right)$, when substituting two acac for hfac ligands. Consistent with the BDFEs in $\mathbf{1}$ and $\mathbf{4}$, complex $\mathbf{1}$ is very rapidly oxidized by TEMPO' to give 3 and TEMPO-H in a net HAT reaction for which $\Delta G^{\circ}=-4.5 \mathrm{kcal} \mathrm{mol}^{-1}$. In contrast, no reaction was observed between 4 and TEMPO', consistent with a very uphill $\Delta G^{\circ}=+13.1 \mathrm{kcal}$ $\mathrm{mol}^{-1}$, and facile reaction occurs in the opposite direction: $\mathrm{Ru}^{\mathrm{III}}(\mathrm{hfac})_{2}(\mathrm{py}-\mathrm{im})(\mathbf{6})+\mathrm{TEMPO}-$ $\mathrm{H} \rightarrow \mathbf{4}+$ TEMPO $^{*}$. Detailed studies of hydrogen atom transfer (HAT) reactions with these systems are underway, including HAT self-exchange, kinetic isotope effects, and application of Marcus cross relation. 


\section{Experimental}

\section{Materials}

All reagent grade solvents were purchased from Fisher Scientific, EMD Chemicals, or Honeywell Burdick \& Jackson (for anhydrous $\mathrm{MeCN}$ ). Various efforts to purify $\mathrm{MeCN}$, including treatments with $\mathrm{CaH}_{2} / \mathrm{P}_{2} \mathrm{O}_{5}$ and various oxidants, have only decreased the stability of strongly oxidizing materials in $\mathrm{MeCN}$ (perhaps due to amine impurities). Therefore the highpurity Burdick \& Jackson MeCN was simply sparged with $\mathrm{N}_{2}$ and piped from a steel keg directly into a glove box. Deuterated solvents were obtained from Cambridge Isotope Laboratories. $\mathrm{CD}_{3} \mathrm{CN}$ was dried over $\mathrm{CaH}_{2}$, vacuum transferred to $\mathrm{P}_{2} \mathrm{O}_{5}$, then over to $\mathrm{CaH}_{2}$, and then to an empty glass vessel. DBU, 2,4-lutidine, TEMPO ${ }^{*}$, and $\left({ }^{n} \mathrm{Bu}_{4} \mathrm{~N}\right) \mathrm{PF}_{6}$ were purchased from Aldrich, HOTf from Acros, and $\mathrm{Et}_{3} \mathrm{~N}$ from Fisher. $\mathrm{Et}_{3} \mathrm{~N}$ was distilled from $\mathrm{KOH}$ and then dried over $\mathrm{CaH}_{2}{ }^{50}$ TEMPO ${ }^{\circ}$ was sublimed onto a cold-finger. $\left({ }^{n} \mathrm{Bu}_{4} \mathrm{~N}\right) \mathrm{PF}_{6}$ was re-crystallized from $\mathrm{EtOH}$ before use. $c i s-\mathrm{Ru}^{\mathrm{II}}(\mathrm{acac})_{2}(\mathrm{MeCN})_{2}, 14$ cis$\left[\mathrm{Ru}^{\mathrm{III}}(\mathrm{acac})_{2}(\mathrm{MeCN})_{2}\right] \mathrm{OTf},{ }^{15}$ cis-Ru${ }^{\mathrm{II}}(\mathrm{hfac})_{2}(\mathrm{MeCN})_{2}, 15$ py-imH, ${ }^{12}$ py-imnH, ${ }^{35}$ TEMPO$\mathrm{H},{ }^{32}$ and $\left[\mathrm{N}(\mathrm{tol})_{3}\right] \mathrm{PF}_{6}{ }^{33}$ were prepared according to literature procedures. All reactions were performed in the absence of air using glove box/vacuum line techniques unless otherwise noted.

\section{Physical Techniques and Instrumentation}

${ }^{1} \mathrm{H}(300$ and $500 \mathrm{MHz}),{ }^{13} \mathrm{C}\left\{{ }^{1} \mathrm{H}\right\}(75$ and $126 \mathrm{MHz})$, and ${ }^{19} \mathrm{~F}(282 \mathrm{MHz}) \mathrm{NMR}$ and ${ }^{1} \mathrm{H} 2 \mathrm{D}$ COSY spectra were recorded on Bruker Avance spectrometers at room temperature, referenced to a residual solvent peak or an external $\mathrm{CF}_{3} \mathrm{C}(\mathrm{O}) \mathrm{OH}$ standard $(\delta-78.50),{ }^{24}$ and reported as: $\delta$ (multiplicity, number of protons, assignment, coupling constant). The error for NMR integration is estimated to be $\pm 10 \%$. Electron impact mass spectra (EI/MS) were obtained on a Kratos Profile HV-3 direct probe instrument. Electrospray ionization mass spectra (ESI/MS) were obtained on a Bruker Esquire-LC ion trap mass spectrometer, and reported as $\mathrm{m} / \mathrm{z}$ for the most abundant peak in a Ru isotopic pattern. Samples were infused as MeCN solutions and acquired in positive or negative ionization mode. UV-vis spectra were acquired with a HewlettPackard 8453 diode array spectrophotometer in anhydrous $\mathrm{MeCN}$, and are reported as $\lambda_{\max } /$ $\mathrm{nm}\left(\varepsilon / \mathrm{M}^{-1} \mathrm{~cm}^{-1}\right)$. CV measurements in $0.1 \mathrm{M}\left({ }^{n} \mathrm{Bu}_{4} \mathrm{~N}\right) \mathrm{PF}_{6} / \mathrm{MeCN}$ were performed using a Pt disc working electrode, a Pt wire auxiliary electrode, and an $\mathrm{Ag}$ wire $/ \mathrm{AgNO}_{3}$ reference electrode with $\mathrm{Cp}_{2} \mathrm{Fe}$ as an internal standard, and potentials are reported vs. $\mathrm{Cp}_{2} \mathrm{Fe}^{+/ 0}( \pm 0.01$ V). Elemental analyses were performed by Atlantic Microlab (Norcross, GA).

\section{Ru"l(acac) $)_{2}$ (py-imH) (1)}

A solution of $c i s-\mathrm{Ru}^{\mathrm{II}}(\mathrm{acac})_{2}(\mathrm{MeCN})_{2}(150 \mathrm{mg}, 0.393 \mathrm{mmol})$ and py-imH $(69 \mathrm{mg}, 0.48 \mathrm{mmol})$ in $\mathrm{C}_{6} \mathrm{H}_{6}(15 \mathrm{~mL})$ was stirred and heated in a $80^{\circ} \mathrm{C}$ oil bath for $5 \mathrm{~h}$ under $\mathrm{N}_{2}$. The solution was cooled to room temperature to yield a brown precipitate, which was filtered by a swivel frit and dried in vacuo. Yield: $136 \mathrm{mg}(78 \%) .{ }^{1} \mathrm{H}$ NMR $\left(\mathrm{CD}_{3} \mathrm{CN}\right): 1.51(6 \mathrm{H}), 2.00(3 \mathrm{H}), 2.05(3 \mathrm{H})$ $\left(\mathrm{s}\right.$, acac- $\left.\mathrm{CH}_{3}\right) ; 5.29,5.32(\mathrm{~s}, 1 \mathrm{H}$ each, acac-CH); $7.09(\mathrm{t}), 7.53(\mathrm{t}), 7.81(\mathrm{~d}), 8.75(\mathrm{~d})(1 \mathrm{H}$ each, py-H, $\left.{ }^{3} J_{\mathrm{HH}}=6-8 \mathrm{~Hz}\right) ; 7.14,7.36\left(\mathrm{~d}, 1 \mathrm{H}\right.$ each, im-CH, $\left.{ }^{3} J_{\mathrm{HH}}=2 \mathrm{~Hz}\right) ; 11.31(\mathrm{~s}, 1 \mathrm{H}, \mathrm{im}-\mathrm{NH})$. An adequate ${ }^{13} \mathrm{C}\left\{{ }^{1} \mathrm{H}\right\}$ NMR spectrum has not been obtained due to low solubility of $\mathbf{1}$. EI/MS: $444[\mathrm{M}-\mathrm{H}]^{+}, 401,344[\mathrm{M}-\mathrm{acacH}]^{+}, 300[\mathrm{M}-\mathrm{py}-\mathrm{imH}]^{+}, 259,247 . \mathrm{UV}-\mathrm{Vis}: 272$ (27000), 428 (6700), 568 (7000). CV: $E_{1 / 2}=-0.64 \mathrm{~V}\left(\mathrm{Ru}^{\mathrm{III} / \mathrm{II}}\right)$. Anal. Calcd (Found) for $\mathrm{C}_{18} \mathrm{H}_{21} \mathrm{~N}_{3} \mathrm{O}_{4} \mathrm{Ru}: \mathrm{C}, 48.64$ (48.84); H, 4.76 (4.71); N, 9.45 (9.18).

\section{[Ru'll'(acac) 2 (py-imH)]OTf (2)}

A solution of $c i s$-[Ru $\left.{ }^{\mathrm{III}}(\mathrm{acac})_{2}(\mathrm{MeCN})_{2}\right] \mathrm{OTf}(150 \mathrm{mg}, 0.283 \mathrm{mmol})$ and py-imH (49 mg, 0.34 mmol) in $\mathrm{C}_{6} \mathrm{H}_{6}(15 \mathrm{~mL})$ was stirred under $\mathrm{N}_{2}$ at $80^{\circ} \mathrm{C}$ for $5 \mathrm{~h}$. The solution was cooled to room temperature to yield a brick-red precipitate, which was filtered by a swivel frit. The solid was re-precipitated with $\mathrm{CH}_{2} \mathrm{Cl}_{2} /$ hexanes, filtered, and dried in vacuo at $78^{\circ} \mathrm{C}$. Yield: $125 \mathrm{mg}$ 
(74\%). ${ }^{1} \mathrm{H}$ NMR $\left(\mathrm{CD}_{3} \mathrm{CN}\right)$ : (all br s) $-21.71(6 \mathrm{H}),-18.88(3 \mathrm{H}),-17.48(3 \mathrm{H})\left(\right.$ acac- $\left.\mathrm{CH}_{3}\right)$; $-64.83,-54.40-23.61,-8.07$ (1H each, acac-CH or im-CH); $-8.87,0.07,2.14,3.91$ (1H each, py-H); $5.71(1 \mathrm{H}, \mathrm{im}-\mathrm{NH})$. EI/MS: $444[\mathrm{M}-\mathrm{H}]^{+}, 401,344[\mathrm{M}-\mathrm{acacH}]^{+}, 300[\mathrm{M}-$ py$\mathrm{imH}]^{+}, 259,247 . \mathrm{ESI} \mathrm{MS}^{+}: 445\left(\mathrm{M}^{+}\right)$; ESI/MS ${ }^{-}: 149$ (OTf $\left.^{-}\right)$. UV-Vis: 288 (20000), 360sh (5000), 520 (2000). CV: $E_{1 / 2}=-0.64 \mathrm{~V}\left(\mathrm{Ru}^{\mathrm{III} / \mathrm{II}}\right)$. Anal. Calcd (Found) for $\mathrm{C}_{19} \mathrm{H}_{21} \mathrm{~N}_{3} \mathrm{O}_{7} \mathrm{~F}_{3} \mathrm{SRu}$ : C, 38.45 (38.27); H, 3.57 (3.59); N, 7.08 (7.31).

\section{$R^{\prime \prime l l}(\text { acac) })_{2}$ (py-im) (3)}

A solution of 1 (200 mg, $0.450 \mathrm{mmol})$ and TEMPO ${ }^{\bullet}(84 \mathrm{mg}, 0.54 \mathrm{mmol})$ in $\mathrm{MeCN}$ (30 mL) was stirred under $\mathrm{N}_{2}$ for $10 \mathrm{~min}$ at room temperature. The solvent was removed under vacuum, and the residue was sublimed for $16 \mathrm{~h}$ with vacuum cold finger apparatus to remove TEMPO$\mathrm{H}$. The product was re-precipitated with $\mathrm{CH}_{2} \mathrm{Cl}_{2}$ /hexanes to yield a dark brown solid, which was filtered and dried in vacuo at $78{ }^{\circ} \mathrm{C}$. Yield: $130 \mathrm{mg}(65 \%) .{ }^{1} \mathrm{H} \mathrm{NMR}\left(\mathrm{CD}_{3} \mathrm{CN}\right)$ : (all br s) $-17.58,-15.52,-11.00,-5.09$ ( $3 \mathrm{H}$ each, acac- $\left.\mathrm{CH}_{3}\right) ;-47.33,-39.08,-21.31,-19.45$ ( $1 \mathrm{H}$ each, acac-CH or im-CH); $-8.56,-4.46,-2.95,8.75$ (1H each, py-H). EI/MS: $444\left(\mathrm{M}^{+}\right), 401,344$ $\left[\mathrm{M}-\mathrm{acac}^{+}, 300[\mathrm{M}-\mathrm{py}-\mathrm{im}]^{+}, 259,247 . \mathrm{ESI}^{+} \mathrm{MS}^{+}: 445[\mathrm{M}+\mathrm{H}]^{+}\right.$. UV-Vis: 286 (19000), 331sh (13000), 486 (1600). CV: $E_{1 / 2}=-1.00 \mathrm{~V}\left(\mathrm{Ru}^{\mathrm{III} / \mathrm{II}}\right)$. Anal. Calcd (Found) for $\mathrm{C}_{18} \mathrm{H}_{20} \mathrm{~N}_{3} \mathrm{O}_{4} \mathrm{Ru} \cdot 0.2 \mathrm{H}_{2} \mathrm{O}: \mathrm{C}, 48.36$ (47.89); $\mathrm{H}, 4.60$ (4.51); N, 9.40 (9.35); ${ }^{1} \mathrm{H}$ NMR spectra of 3 in $\mathrm{CD}_{3} \mathrm{CN}$ typically show $\sim 0.2$ equivalents of $\mathrm{H}_{2} \mathrm{O}$ per Ru although an NMR spectrum of the batch sent for elemental analysis was not obtained.

\section{$\mathrm{Ru}^{\mathrm{Il}}(\mathrm{hfac})_{2}$ (py-imH) (4)}

A solution of $c i s-\mathrm{Ru}^{\mathrm{II}}(\mathrm{hfac})_{2}(\mathrm{MeCN})_{2}(1000 \mathrm{mg}, 1.67 \mathrm{mmol})$ and py-imH $(420 \mathrm{mg}, 2.89 \mathrm{mmol})$ in $\mathrm{C}_{6} \mathrm{H}_{6}(50 \mathrm{~mL})$ was refluxed for $16 \mathrm{~h}$ under air. The solvent was removed on a rotary evaporator, and the residue was loaded onto a silica gel column and eluted with 9:1 $\mathrm{CH}_{2} \mathrm{Cl}_{2}$ / $\mathrm{CH}_{3} \mathrm{OH}$. The first brown fraction was unreacted cis- $\mathrm{Ru}^{\mathrm{II}}(\mathrm{hfac})_{2}(\mathrm{MeCN})_{2}(207 \mathrm{mg}, 21 \%)$, and 4 was isolated as the second red-brown fraction, which was rotary evaporated to dryness, reprecipitated with $\mathrm{CH}_{2} \mathrm{Cl}_{2} /$ hexanes, filtered, and dried in vacuo at $78^{\circ} \mathrm{C}$. Yield: $298 \mathrm{mg}$ (27\%). ${ }^{1} \mathrm{H}$ NMR ( $\left.\mathrm{CD}_{3} \mathrm{CN}\right): 6.20$ (s, 2H, hfac-H); 7.42 (t), 7.97 (t), 8.09 (d), 8.48 (d) (1H each, py-H, $\left.{ }^{3} J_{\mathrm{HH}}=6-8 \mathrm{~Hz}\right) ; 7.22,7.49\left(\mathrm{~d}, 1 \mathrm{H}\right.$ each, im-CH, $\left.{ }^{3} J_{\mathrm{HH}}=2 \mathrm{~Hz}\right) ; 11.82(\mathrm{~s}, 1 \mathrm{H}, \mathrm{im}-$ NH). ${ }^{19} \mathrm{~F} \mathrm{NMR}\left(\mathrm{CD}_{3} \mathrm{CN}\right):-75.06,-75.04,-74.99,-74.94\left(\mathrm{~s}\right.$, hfac- $\left.-\mathrm{CF}_{3}\right) .{ }^{13} \mathrm{C}\left\{{ }^{1} \mathrm{H}\right\}$ NMR $\left(\mathrm{CD}_{3} \mathrm{OD}\right): 92.81,93.00(\mathrm{hfac}-\mathrm{CH}) ; 117.84,117.86,119.02,119.09\left(\mathrm{q}, \mathrm{hfac}_{-} \mathrm{CF}_{3}, 1_{J_{\mathrm{CF}}}=282\right.$ $\mathrm{Hz}) ; 120.83,124.81,137.99,153.41$ (py-CH); 121.53, 132.38 (im-CH); 149.67, 153.26 (pyN-C-C-N-im); 168.94, 169.10, 172.35, 172.53 (q, hfac-C(O), $\left.{ }^{2} J_{\mathrm{CF}}=33 \mathrm{~Hz}\right) . \mathrm{ESI}^{\mathrm{M}} \mathrm{MS}^{+}: 661$ $\left(\mathrm{M}^{+}\right)$. UV-Vis: 291 (26000), 481 sh (9600), 519 (10000). CV: $E_{1 / 2}=0.29 \mathrm{~V}\left(\mathrm{Ru}^{\mathrm{III} / \mathrm{II}}\right)$. Anal. Calcd (Found) for $\mathrm{C}_{18} \mathrm{H}_{9} \mathrm{~F}_{12} \mathrm{~N}_{3} \mathrm{O}_{4} \mathrm{Ru}$ : C, 32.74 (32.80); H, 1.37 (1.38); N, 6.36 (6.54).

\section{[DBU-H][Ru"(hfac) $)_{2}$ (py-im)] (5)}

DBU $(25 \mu \mathrm{L}, 0.165 \mathrm{mmol})$ was added to a red-brown solution of $4(109 \mathrm{mg}, 0.165 \mathrm{mmol})$ in $\mathrm{MeCN}(10 \mathrm{~mL})$ under air to immediately generate a dark purple solution, which was rotary evaporated to dryness. The residue was re-precipitated with $\mathrm{CH}_{2} \mathrm{Cl}_{2}$ /hexanes to yield a blackpurple solid, which was filtered and dried in vacuo at $78^{\circ} \mathrm{C}$. Yield: $102 \mathrm{mg}(76 \%) .{ }^{1} \mathrm{H}$ NMR $\left(\mathrm{CD}_{3} \mathrm{CN}\right): 1.70(\mathrm{~m}, 6 \mathrm{H}), 1.98$ (quintet, $\left.2 \mathrm{H}\right), 2.60(\mathrm{~m}, 2 \mathrm{H}), 3.30(\mathrm{t}, 2 \mathrm{H}), 3.46(\mathrm{t}, 2 \mathrm{H}), 3.52(\mathrm{~m}$, 2H) $\left(\right.$ DBU-H $\left.{ }^{+}\right) ; 6.11,6.12$ (s, 1H each, hfac-H); 7.06 (t), 7.71 (t), 7.87 (d), 8.21 (d) (1H each, py-H, $\left.{ }^{3} J_{\mathrm{HH}}=6-8 \mathrm{~Hz}\right) ; 6.99,7.19\left(\mathrm{~d}, 1 \mathrm{H}\right.$ each, im-CH, $\left.{ }^{3} J_{\mathrm{HH}}=2 \mathrm{~Hz}\right) .{ }^{19} \mathrm{~F} \mathrm{NMR}\left(\mathrm{CD}_{3} \mathrm{CN}\right)$ : $-75.06,-74.91,-74.88,-74.74$ (s, hfac- $\left.\mathrm{CF}_{3}\right) .{ }^{13} \mathrm{C}\left\{{ }^{1} \mathrm{H}\right\}$ NMR (CD $\left.3 \mathrm{OD}\right): 20.43,24.94,27.49$, 29.96, 33.78, 39.42, 49 (overlapped with $\mathrm{CD}_{3} \mathrm{OD}$ ), 55.36 (DBU- $\mathrm{CH}_{2}$ ); $93.38,93.47$ (hfac-CH); $118.23,119.74,119.58\left(\mathrm{q}, \mathrm{hfac}-\mathrm{CF}_{3}, 1_{J_{\mathrm{CF}}}=282 \mathrm{~Hz}\right.$ ), the fourth quartet is obscured by overlapping with py-CH; 118.56, 121.18, 137.01, 152.09 (py-CH); 129.80, 132.11 (im-CH); 155.76, 167.45 (py-N-C-C-N-im); 158.29 (DBU-N=C-N); 165.70, 166.68, 170.13, 170.83 (q, hfac-C $\left.(\mathrm{O}),{ }^{2} J_{\mathrm{CF}}=33 \mathrm{~Hz}\right) . \mathrm{ESI} / \mathrm{MS}^{+}: 661[\mathrm{M}+\mathrm{H}]^{+}, 153\left(\mathrm{DBU}^{+}{ }^{+}\right)$; ESI/MS ${ }^{-}: 660\left(\mathrm{M}^{-}\right) . \mathrm{UV}^{-}$ 
Vis: 292 (20000), 472 (8300), 564 (11000). CV: $E_{1 / 2}=-0.07 \mathrm{~V}\left(\mathrm{Ru}^{\mathrm{III} / I I}\right)$. Anal. Calcd (Found) for $\mathrm{C}_{27} \mathrm{H}_{25} \mathrm{~F}_{12} \mathrm{~N}_{5} \mathrm{O}_{4} \mathrm{Ru}$ : C, 39.91 (39.92); H, 3.10 (3.11); N, 8.62 (8.74).

\section{In Situ Generation of Ru'll(hfac) ${ }_{\mathbf{2}}(\mathrm{py}-\mathrm{im})$ (6) and Reaction of $\mathbf{6}+\mathrm{TEMPO}-\mathrm{H}$}

In a $\mathrm{N}_{2}$ glove box, solutions of $5(2.5 \mathrm{mM}, 4.0 \mathrm{mg}$ in $2.0 \mathrm{~mL})$, [N(tol $\left.)_{3}\right] \mathrm{PF}_{6}(61.5 \mathrm{mM}, 26.6$ $\mathrm{mg}$ in $1 \mathrm{~mL})$, and TEMPO-H (123 mM, $38.7 \mathrm{mg}$ in $2.0 \mathrm{~mL})$ in $\mathrm{CD}_{3} \mathrm{CN}$ were prepared at room temperature. A trace amount of $\left(\mathrm{Me}_{3} \mathrm{Si}\right)_{2} \mathrm{O}$ was added to the solution of 5 as internal standard. Each of three J-Young NMR tubes were filled with $0.5 \mathrm{~mL}$ of the solution of 5 . To tubes 2 and 3 was added 1 equiv of $\left[\mathrm{N}\left(\mathrm{tol}_{3}\right)_{3}\right] \mathrm{PF}_{6}(20 \mu \mathrm{L})$, with immediate color changes from purple-red to pale-brown 6 . After mixing tube 3 well, 1 equiv of TEMPO-H $(10 \mu \mathrm{L})$ was added, giving an immediate color change to red-brown 4 . The ${ }^{1} \mathrm{H}$ NMR spectrum of tube 2 after $\sim 20$ min showed resonances of DBU-H ${ }^{+}, \mathrm{N}(\mathrm{tol})_{3}\left[\delta 2.27\left(\mathrm{~s}, 9 \mathrm{H}, \mathrm{CH}_{3}\right) ; 6.87,7.07(\mathrm{~d}, 6 \mathrm{H}\right.$ each, $\mathrm{Ar}-\mathrm{H}$, ${ }^{3} J_{\mathrm{HH}}=7 \mathrm{~Hz}$ )] , and a trace of 4 ; paramagnetic 6 was not observed. The ${ }^{1} \mathrm{H}$ NMR spectrum of tube 3 showed $100 \pm 10 \%$ yield for $\mathbf{4}$, based on integration of starting $\mathbf{5}$. The generation of $\mathbf{6}$ was also monitored by UV-vis titration (Figure S4). Inside a glove box, solutions of $\mathbf{5}(0.053$ $\mathrm{mM}),\left[\mathrm{N}(\mathrm{tol})_{3}\right] \mathrm{PF}_{6}(2.7 \mathrm{mM})$, and TEMPO-H $(2.7 \mathrm{mM})$ in MeCN were prepared at room temperature. An aliquot of $5(2.5 \mathrm{~mL})$ in a UV-vis cuvette was titrated with 0.1 equiv $(5 \mu \mathrm{L})$ increments of $\left[\mathrm{N}(\mathrm{tol})_{3}\right] \mathrm{PF}_{6}$ until 1 equiv, as 6 was generated. UV-Vis of 6: 455 (4700), 508 (3400). The solution was further titrated with increments of 0.1 equiv $(5 \mu \mathrm{L})$ of TEMPO-H until 1 equiv, as 4 was produced. The yield for 4 was $100 \pm 10 \%$ based on starting $\mathbf{5}$. CV: $E_{1 / 2}=-0.07 \mathrm{~V}\left(\mathrm{Ru}^{\mathrm{III} / \mathrm{II}}\right)$ for $\mathbf{6}$, generated from $5(2.5 \mathrm{mM}, 2.0 \mathrm{~mL})+1$ equiv of $\left[\mathrm{N}(\mathrm{tol})_{3}\right] \mathrm{PF}_{6}$ $(62 \mathrm{mM}, 80 \mu \mathrm{L})$ in $\mathrm{MeCN}$.

\section{$\left.\mathrm{Ru}^{\text {Il(acac) }}\right)_{\mathbf{2}}$ (py-imnH) (7)}

Complex 7 was synthesized analogous to 1 using cis $-\mathrm{Ru}^{\mathrm{II}}(\mathrm{acac})_{2}(\mathrm{MeCN})_{2}(200 \mathrm{mg}, 0.52$ $\mathrm{mmol})$ and py-imnH (93 mg, $0.63 \mathrm{mmol})$, and was isolated as a black-green powder. Yield: $121 \mathrm{mg}(52 \%) .{ }^{1} \mathrm{H}$ NMR $\left(\mathrm{CD}_{3} \mathrm{CN}\right): 1.55(3 \mathrm{H}), 1.60(3 \mathrm{H}), 2.00(6 \mathrm{H})\left(\mathrm{s}, \mathrm{acac}_{-} \mathrm{CH}_{3}\right) ; 3.6-4.0$ (m, 4H, imn-CH), 5.27, 5.31 (s, 1H each, acac-CH); $6.12(\mathrm{~s}, 1 \mathrm{H}, \mathrm{imn}-\mathrm{NH}) ; 7.12(\mathrm{t}), 7.49(\mathrm{t})$, $7.61(\mathrm{~d}), 8.74(\mathrm{~d})\left(1 \mathrm{H}\right.$ each, py-H, $\left.{ }^{3} J_{\mathrm{HH}}=6-8 \mathrm{~Hz}\right)$. An adequate ${ }^{13} \mathrm{C}\left\{{ }^{1} \mathrm{H}\right\}$ NMR spectrum has not been obtained due to low solubility of $7 \mathrm{EI} / \mathrm{MS}: 447[\mathrm{M}] .^{+}, 348[\mathrm{M}-\mathrm{acac}]^{+}, 300[\mathrm{M}-$ py$\mathrm{imnH}]^{+}, 282,276,260$, 248. UV-Vis: 274 (24000), 428 (6900), 610 (7700). CV: $E_{1 / 2}=-0.68$ $\mathrm{V}\left(\mathrm{Ru}^{\mathrm{III} / \mathrm{II}}\right)$. Anal. Calcd (found) for $\mathrm{C}_{18} \mathrm{H}_{23} \mathrm{~N}_{3} \mathrm{O}_{4} \mathrm{Ru}$ : C, 48.42 (48.13); H, 5.19 (5.26); N, 9.41 (9.38).

\section{$\mathrm{Ru}^{\mathrm{ll}}(\mathrm{hfac})_{2}(\mathrm{py}$-imnH) (8)}

Complex 8 was synthesized analogous to 4 except using $c i s-\mathrm{Ru}^{\mathrm{II}}(\mathrm{hfac})_{2}(\mathrm{MeCN})_{2}(200 \mathrm{mg}$, $0.33 \mathrm{mmol}$ ) and py-imnH (99 $\mathrm{mg}, 0.67 \mathrm{mmol})$, and was isolated as a brown-purple powder. Yield: $62 \mathrm{mg}(28 \%) .{ }^{1} \mathrm{H}$ NMR $\left(\mathrm{CD}_{3} \mathrm{CN}\right): 3.72(1 \mathrm{H}), 3.85(1 \mathrm{H}), 4.00(2 \mathrm{H})(\mathrm{m}$, imn-CH); 6.17, 6.20 (s, 1H each, hfac-H); 6.90 (s, 1H, imn-NH); 7.50 (t), 7.95 (t), 7.97 (d), 8.54 (d) (1H each, py-H, $\left.{ }^{3} J_{\mathrm{HH}}=6-8 \mathrm{~Hz}\right) .{ }^{19} \mathrm{~F}$ NMR $\left(\mathrm{CD}_{3} \mathrm{CN}\right):-75.14,-75.11,-75.01,-74.83$ (s, hfac$\left.\mathrm{CF}_{3}\right) .{ }^{13} \mathrm{C}\left\{{ }^{1} \mathrm{H}\right\}$ NMR $\left(\mathrm{CD}_{3} \mathrm{OD}\right): 46.12,55.58$ (imn-CH); 92.86 (both hfac-CH); 117.89, $117.96,119.04,119.12$ (q, hfac- $\mathrm{CF}_{3}, 1_{J_{\mathrm{CF}}}=282 \mathrm{~Hz}$ ); 125.02, 127.16, 137.45, 153.84 (py-CH); $152.92,169.34$ (py-N-C-C-N-imn); 168.22, 169.59, 172.25, 172.50 (q, hfac-C(O), ${ }^{2} J_{\mathrm{CF}}=33$ Hz). ESI/MS ${ }^{+}$: $663\left(\mathrm{M}^{+}\right)$. UV-Vis: 225 (6200), 269 (5300), 289 (5300), 484sh (4200), 524 (5300). CV: $E_{1 / 2}=0.14 \mathrm{~V}\left(\mathrm{Ru}^{\mathrm{III} / \mathrm{II}}\right)$. Anal. Calcd (Found) for $\mathrm{C}_{18} \mathrm{H}_{11} \mathrm{~F}_{12} \mathrm{~N}_{3} \mathrm{O}_{4} \mathrm{Ru}: \mathrm{C}, 32.64$ (32.82); H, 1.67 (1.67); N, 6.34 (6.30).

\section{${ }^{1} \mathrm{H}$ NMR Titration of 2 and 3}

Stock solutions were prepared for DBU $(111 \mathrm{mM}, 16.9 \mathrm{mg}$ in $1 \mathrm{~mL})$ and HOTf $(111 \mathrm{mM}, 16.7$ $\mathrm{mg}$ in $1 \mathrm{~mL})$ in $\mathrm{CD}_{3} \mathrm{CN}$. A solution of 3 in an NMR tube (11 mM, $2.5 \mathrm{mg}$ in $0.5 \mathrm{~mL} \mathrm{CD} \mathrm{CDN}_{3} \mathrm{CN}$ was titrated to 2 by adding 1 equiv of HOTf in 0.1 equiv $(5 \mu \mathrm{L})$ increments. ${ }^{1} \mathrm{H}$ NMR spectra 
were recorded initially and after each addition of HOTf. Each peak in the spectra was a weighted average of the corresponding peaks for $\mathbf{2}$ and $\mathbf{3}$, indicating fast proton exchange on the NMR time scale. The reverse titration, adding 1 equiv of DBU in 0.1 equiv $(5 \mu \mathrm{L})$ increments, was also monitored by ${ }^{1} \mathrm{H}$ NMR.

\section{UV-vis Titration of 2 and $p K_{\mathrm{a}}$ Determination}

Stock solutions were prepared for $2(0.11 \mathrm{mM})$, DBU $(6.5 \mathrm{mM})$, and HOTf $(6.5 \mathrm{mM})$ in MeCN. An aliquot of $2(3.0 \mathrm{~mL}, 0.11 \mathrm{mM})$ was transferred to a UV-vis cuvette and was titrated with increments of 0.1 equiv $(5 \mu \mathrm{L})$ of DBU. UV-vis spectra were recorded for the initial 2 and after each addition of DBU. A total of 1.3 equiv of DBU was added, but the spectrum stopped changing after 1.0 equiv, showing a stoichiometric conversion to the deprotonated 3 . The titration was reversible, and protonated 2 was regenerated stoichiometrically by 1 equiv of HOTf, by adding 0.1 equiv $(5 \mu \mathrm{L})$ increments.

A stock solution of 2,4-lutidine $(647 \mathrm{mM})$ in $\mathrm{MeCN}$ was prepared, and was serial diluted twice to make two other solutions $(64.7 \mathrm{mM}$ and $6.47 \mathrm{mM})$. An aliquot of $2(3.0 \mathrm{~mL}, 0.11 \mathrm{mM})$ was transferred to a UV-vis cuvette, and was titrated with increments of 0.1 equiv $(5 \mu \mathrm{L})$ of 2,4lutidine $(6.47 \mathrm{mM})$ until 2.0 equiv. The titration was continued by adding 1 equiv $(5 \mu \mathrm{L})$ of $64.7 \mathrm{mM}$ base until 20 equiv, and then with 10 equiv $(5 \mu \mathrm{L})$ of $647 \mathrm{mM}$ base until 200 equiv. $\mathrm{UV}$-vis spectra were recorded for the initial 2 and after each addition of 2,4-lutidine. The UVvis data were analyzed using the absorbance at $340 \mathrm{~nm}$, yielding $[3] /[2]=\left(\mathrm{A}-\mathrm{A}_{\mathbf{2}}\right) /\left(\mathrm{A}_{\mathbf{3}}-\mathrm{A}\right)$, where $\mathrm{A}_{\mathbf{2}}$ and $\mathrm{A}_{\mathbf{3}}$ are the absorbances for pure $\mathbf{2}$ and $\mathbf{3}$ at $340 \mathrm{~nm}$ : [3] $=\left[2,4\right.$-lutidine- $\left.\mathrm{H}^{+}\right]=$ $\left\{\left(\left(\mathrm{A}-\mathrm{A}_{\mathbf{2}}\right) /\left(\mathrm{A}_{\mathbf{3}}-\mathrm{A}_{\mathbf{2}}\right)\right) \times[\mathrm{Ru}]_{\text {total }}\right\}$ and $[2,4$-lutidine $]=[2,4 \text {-lutidine }]_{\text {total }}-\left[2,4\right.$-lutidine- $\left.\mathrm{H}^{+}\right]=$ $[2,4-\text { lutidine }]_{\text {total }}-\left\{\left(\left(\mathrm{A}-\mathrm{A}_{\mathbf{2}}\right) /\left(\mathrm{A}_{\mathbf{3}}-\mathrm{A}_{\mathbf{2}}\right)\right) \times[\mathrm{Ru}]_{\text {total }}\right\}$. Plotting [3][2,4-lutidine- $\left.\mathrm{H}^{+}\right] /[\mathbf{2}] v s$. [2,4-lutidine] yielded a straight line (Figure S3), whose slope is $K_{\mathrm{eq}}=0.011 \pm 0.001$ for $2+$ 2,4-lutidine $\rightleftarrows \mathbf{3}+\left(2,4-\right.$ lutidine-H)OTf. The $\mathrm{p} K_{\mathrm{a}}$ of $\mathbf{2}$ was calculated from $\mathrm{p} K_{\mathrm{a}}(\mathbf{2})=\mathrm{p} K_{\mathrm{a}}(2,4-$ lutidine- $\left.\mathrm{H}^{+}\right)-\log K_{\mathrm{eq}}=16.0 \pm 0.1$ using the known $\mathrm{p} K_{\mathrm{a}}$ of $14.05^{27}$ for 2,4 -lutidine- $\mathrm{H}^{+}$.

\section{UV-vis Titration of 4 and $\mathrm{p} K_{\mathrm{a}}$ Determination}

Following the procedure above, $3.0 \mathrm{~mL}$ of a $0.033 \mathrm{mM}$ solution of 4 was titrated with DBU $(19.6 \mathrm{mM})$ and then with HOTf $(19.7 \mathrm{mM})$ (all in MeCN). 1 equiv of DBU completely converted $\mathbf{4}$ to 5 , which was converted back to $\mathbf{4}$ by 1 equiv of HOTf. Again following the procedure above, $4(3.0 \mathrm{~mL}, 0.030 \mathrm{mM})$ was titrated with solutions of $\mathrm{Et}_{3} \mathrm{~N}$, adding 0.1 equiv $(5 \mu \mathrm{L})$ of $\mathrm{Et}_{3} \mathrm{~N}(1.78 \mathrm{mM})$ until 2.0 equiv, then adding 1 equiv $(5 \mu \mathrm{L})$ of $\mathrm{Et}_{3} \mathrm{~N}(17.8 \mathrm{mM})$ until 20 equiv. UV-vis spectra were recorded for the initial $\mathbf{4}$ and after each addition of $\mathrm{Et}_{3} \mathrm{~N}$, and the data were analyzed using the absorbance at $565 \mathrm{~nm}$. The plot of $[5]\left[\mathrm{Et}_{3} \mathrm{NH}^{+}\right] /[4] v s$.

$\left[\mathrm{Et}_{3} \mathrm{~N}\right]$ yielded a straight line with slope $K_{\mathrm{eq}}=0.14 \pm 0.01$. The $\mathrm{p} K_{\mathrm{a}}$ of 4 is given by $\mathrm{p} K_{\mathrm{a}}(4)=$ $\mathrm{p} K_{\mathrm{a}}\left(\mathrm{Et}_{3} \mathrm{NH}^{+}\right)-\log K_{\mathrm{eq}}=19.3 \pm 0.1$ using $\mathrm{p} K_{\mathrm{a}}=18.46$ for $\mathrm{Et}_{3} \mathrm{NH}^{+.27}$

\section{${ }^{1}$ H NMR Reactions with TEMPO•}

Many reactions were monitored by ${ }^{1} \mathrm{H}$ NMR in sealable J-Young tubes. In a typical procedure, solutions of $1(1.8 \mathrm{mM}, 1.6 \mathrm{mg}$ in $2 \mathrm{~mL})$ and TEMPO $(90 \mathrm{mM}, 28.0 \mathrm{mg}$ in $2 \mathrm{~mL})$ were prepared in $\mathrm{CD}_{3} \mathrm{CN}$ in a $\mathrm{N}_{2}$ glove box. A trace of $\left(\mathrm{Me}_{3} \mathrm{Si}\right)_{2} \mathrm{O}$ was added to the solution of $\mathbf{1}$ as internal standard. Each of the two J-Young tubes was charged with $0.5 \mathrm{~mL}$ of the solution of $\mathbf{1}$.

TEMPO $^{\circ}(1$ equiv, $10 \mu \mathrm{L}$ ) was added to one of the tubes, accompanied by instant color change from red-purple to pale-brown. ${ }^{1} \mathrm{H}$ NMR spectra of $\mathbf{1}$ and $\mathbf{1}+\mathrm{TEMPO}^{\circ}$ were recorded after $\sim 20 \mathrm{~min}$, the latter showing the product yield for 3 (86\%) and TEMPO-H (98\%) [TEMPO$\left.\mathrm{H}:-1.06\left(\mathrm{~s}, 12 \mathrm{H}, \mathrm{CH}_{3}\right), 1.45\left(\mathrm{~s}, 6 \mathrm{H}, \mathrm{CH}_{2}\right), 5.34(\mathrm{~s}, 1 \mathrm{H}, \mathrm{OH})\right] .{ }^{32}$ The ${ }^{1} \mathrm{H}$ NMR spectrum of $4(3.0 \mathrm{mM}, 0.5 \mathrm{~mL})$ and 36 equiv of TEMPO $(8.5 \mathrm{mg})$ in $\mathrm{CD}_{3} \mathrm{CN}$ showed only resonances for 4 and TEMPO ${ }^{\circ}$ at room temperature after $1 \mathrm{~d}$ [TEMPO ${ }^{\circ} \delta-29.74\left(4 \mathrm{H}, 3,5-\mathrm{CH}_{2}\right),-16.51$ $\left(12 \mathrm{H}, \mathrm{CH}_{3}\right), 15.33\left(2 \mathrm{H}, 4-\mathrm{CH}_{2}\right)$ (all br s)]. 


\section{X-ray Structural Determinations}

Crystals of 1 were grown from slow evaporation of $\mathrm{MeCN} / \mathrm{C}_{6} \mathrm{H}_{6}$ solutions inside as $\mathrm{N}_{2}$ glove box. Crystals of 2-5, and $\mathbf{8}$ were grown by vapor diffusion of $\mathrm{Et}_{2} \mathrm{O} /$ hexanes to $\mathrm{CH}_{2} \mathrm{Cl}_{2}$ solutions of the complex under air. The crystals were mounted onto glass capillaries with oil. The data were collected on a Nonius Kappa CCD diffractometer. The data were integrated and scaled using $h k l$-SCALEPACK. ${ }^{51}$ This program applies multiplicative correction factor $(S)$ to the observed intensities $(I)$ and has the following form: $S=\exp \left(-2 B(\sin 2 \theta) / \lambda^{2}\right) /$ scale. $S$ is calculated from the scale and $B$ factor determined for each frame and is then applied to $I$ to give the corrected intensity $\left(I_{\text {corr }}\right)$. Solution by direct methods (SIR97) produced a complete heavy atom phasing model consistent with the proposed structure. ${ }^{52}$ All hydrogen atoms were located using a riding model. All non-hydrogen atoms were refined anisotropically by fullmatrix least-squares (SHELXL-97) ${ }^{53}$ Half of a solvent molecule is found in the unit cells of $\mathbf{1}\left(0.5 \mathrm{C}_{6} \mathrm{H}_{6}\right)$ and $2\left(0.5 \mathrm{CH}_{2} \mathrm{Cl}_{2}\right)$. In the structures of $\mathbf{4}$ and $\mathbf{8}$, each of the unit cells contains two independent ruthenium complexes. The structure of $\mathbf{5}$ contains a disordered $\mathrm{CF}_{3}$ group, with major F1, F2, and F3 and minor F1A, F2A, and F3A components (Figure S5); only the major fluorine atoms are shown in Figure $2 \mathrm{~b}$. The major to minor occupancy was modeled as $80 \%$ and $20 \%$, and the thermal ellipsoids for minor components F1A, F2A, and F3A were restrained during refinement.

\section{Supplementary Material}

Refer to Web version on PubMed Central for supplementary material.

\section{Acknowledgements}

We would like to thank the U.S. National Institutes of Health (GM50422) for financial support of this work. J. Masland also thanks Ithaca College Dana Internship Program for a summer fellowship. We acknowledge Mr. Eric Carter and Dr. Mira Kanzelberger for preliminary studies of benzimidazole systems, Ms. Elizabeth Mader for valuable discussions, and Mr. Loren Kruse for assistance with mass spectrometry.

\section{References}

1. (a) Cukier RI, Nocera DG. Annu Rev Phys Chem 1998;49:337. [PubMed: 9933908]Hodgkiss, JM.; Rosenthal, J.; Nocera, DG. Hydrogen-Transfer Reactions. Hynes, JT.; Klinman, JP.; Limbach, H-H.; Schowen, RL., editors. 2. Wiley-VCH; Weinheim: 2007. p. 503-562. (c) Stubbe J, Nocera DG, Yee CS, Chang MCY. Chem Rev 2003;103:2167. [PubMed: 12797828]Hammes-Schiffer, S. HydrogenTransfer Reactions. Hynes, JT.; Klinman, JP.; Limbach, H-H.; Schowen, RL., editors. 2. Wiley-VCH; Weinheim: 2007. p. 479-502. (e) Meyer TJ, Huynh MHV. Inorg Chem 2003;42:8140. [PubMed: 14658865]

2. (a) Mayer JM. Annu Rev Phys Chem 2004;55:363. [PubMed: 15117257] (b) Mayer JM, Rhile IJ. Biochim Biophys Acta 2004;1655:51. [PubMed: 15100016] (c) Mayer JM, Rhile IJ, Larsen FB, Mader EA, Markle TF, DiPasquale AG. Photosynth Res 2006;87:3. [PubMed: 16437185] (d) Mayer JM, Mader EA, Roth JP, Bryant JR, Matsuo T, Dehestani A, Bales BC, Watson EJ, Osako T, ValliantSaunders K, Lam W-H, Hrovat DA, Borden WT, Davidson ER. J Mol Catal A: Chem 2006;251:24.

3. Mayer JM. Acc Chem Res 1998;31:441.

4. Knapp, MJ.; Meyer, M.; Klinman, JP. Hydrogen-Transfer Reactions. Hynes, JT.; Klinman, JP.; Limbach, H-H.; Schowen, RL., editors. 4. Wiley-VCH; Weinheim: 2007. p. 1241-1284. (b) Knapp MJ, Rickert K, Klinman JP. J Am Chem Soc 2002;124:3865. [PubMed: 11942823] (c) Glickman MH, Klinman JP. Biochemistry 1996;35:12882. [PubMed: 8841132]

5. There are also many examples of HAT involving metal hydride complexes, for instance: (a) Song JS, Bullock RM, Creutz C. J Am Chem Soc 1991;113:9862. (b) Edidin RT, Sullivan JM, Norton JR. J Am Chem Soc 1987;109:3945. 
6. (a) Roth JP, Lovell S, Mayer JM. J Am Chem Soc 2000;122:5486. (b) Roth JP, Mayer JM. Inorg Chem 1999;38:2760. [PubMed: 11671018] (c) Burnett MG, McKee V, Nelson SM. J Chem Soc, Dalton Trans 1981:1492. (d) Wang JC, Bauman JE Jr. Inorg Chem 1965;4:1613.

7. (a) Roth JP, Yoder JC, Won TJ, Mayer JM. Science 2001;294:2524. [PubMed: 11752572] (b) Mader EA, Davidson ER, Mayer JM. J Am Chem Soc 2007;129:5153. [PubMed: 17402735] (c) Mader EA, Larsen AS, Mayer JM. J Am Chem Soc 2004;126:8066. [PubMed: 15225018] (d) Yoder JC, Roth JP, Gussenhoven EM, Larsen AS, Mayer JM. J Am Chem Soc 2003;125:2629. [PubMed: 12603151]

8. (a) Wherland S. Coord Chem Rev 1993;123:169.Meyer, TJ.; Taube, H. Comprehensive Coordination Chemistry. Wilkinson, G., editor. 1. Pergamon; New York: 1987. p. 331-384.

9. (a) Lomoth R, Magnuson A, Sjödin M, Huang P, Styring S, Hammarström L. Photosynth Res 2006;87:25. [PubMed: 16416050] (b) Sjödin M, Styring S, Wolpher H, Xu Y, Sun L, Hammarström L. J Am Chem Soc 2005;127:3855. [PubMed: 15771521]

10. Cape JL, Bowman MK, Kramer DM. J Am Chem Soc 2005;127:4208. [PubMed: 15783202]

11. (a) Roberts JA, Kirby JP, Nocera DG. J Am Chem Soc 1995;117:8051. (b) Kirby JP, Roberts JA, Nocera DG. J Am Chem Soc 1997;119:9230.

12. Hughey JL IV, Knapp S, Schugar H. Synthesis 1980;6:489.

13. (a) Haga M. Inorg Chim Acta 1983;75:29. (b) Haga M, Tsunemitsu A. Inorg Chim Acta 1989;164:137.

14. Baird IR, Cameron BR, Skerlj RT. Inorg Chim Acta 2003;353:107.

15. Baird IR, Rettig SJ, James BR, Skov KA. Can J Chem 1999;77:1821.

16. El-Hendawy AM, Alqaradawi SY, Al-Madfa HA. Transition Met Chem 2000;25:572.

17. Haga M. Inorg Chim Acta 1983;77:L39.

18. Carter E, Kanzelberger MA. 2003Unpublished data

19. Potential converted from $\mathrm{Ru}^{\mathrm{III} / \mathrm{II}} E_{1 / 2}=1.17 \mathrm{~V}$ s. SCE using $E_{1 / 2}\left(\mathrm{Cp}_{2} \mathrm{Fe}^{+/ 0}\right)=0.31 \mathrm{~V} v$ s. SCE. ${ }^{13 a}$

20. (a) $\mathrm{Ru}^{\mathrm{II}}(\mathrm{acac})_{2}$ (3-amino-6-(3,5-dimethylpyrazol-1-yl)-1,2,4,5-tetrazine): Nayak A, Patra S, Sarkar B, Ghumaan S, Puranik VG, Kaim W, Lahiri GK. Polyhedron 2005;24:333.(b) cis- and trans$\mathrm{Ru}^{\mathrm{II}}(\mathrm{acac})_{2} \mathrm{~L}_{2},\left[\mathrm{Ru}^{\mathrm{III}}(\mathrm{acac})_{2}(\mathrm{~L})\right]\left(\mathrm{ClO}_{4}\right)$, and trans-[Ru $\left.\left.\mathrm{RII}_{(\mathrm{acac}}\right)_{2}(\mathrm{~L})_{2}\right]-\left(\mathrm{ClO}_{4}\right)\left(\mathrm{L}=2,2^{\prime}-\right.$ dipyridylamine): Kar S, Chanda N, Mobin SM, Urbanos FA, Niemeyer M, Puranik VG, JimenezAparicio R, Lahiri GK. Inorg Chem 2005;44:1571. [PubMed: 15733000](c) Ru ${ }^{\mathrm{II}}(\mathrm{acac})_{2}$ (obenzoquinonediimine) and $\mathrm{Ru}^{\mathrm{II}}(\mathrm{acac})_{2}$ (N-phenyl-1,2-benzoquinonediimine): Mitra KN, Choudhury S, Castiòeiras A, Goswami S. J Chem Soc, Dalton Trans 1998:2901.

21. Reported structures for Ru-hfac complexes: (a) cis-Ru ${ }^{\mathrm{II}}(\mathrm{hfac})_{2}(\mathrm{MeCN})_{2}$, cis-Ru ${ }^{\mathrm{II}}(\mathrm{acac})(\mathrm{hfac})$ $(\mathrm{MeCN})_{2}, \mathrm{Ru}^{\mathrm{III}}(\mathrm{hfac})_{3}$ : ref. 15; (b) cis-RuII $(\mathrm{hfac})_{2}(\mathrm{CO})_{2}$ : Lee, F.-J.; Chi, Y.; Liu, C.-S.; Hsu, P.-F.; Chou, T.-Y.; Peng, S.-M.; Lee, G.-H. Chem. Vap. Deposition 2001, 7, 99 (which reports slightly longer Ru-O distances, 2.050(2)-2.081(2) $\AA$, compared to those in 4 and 5); (c) cis- and trans$\mathrm{Ru}^{\mathrm{III}} \mathrm{Cl}_{2}$ (hfac) $\left(\mathrm{PPh}_{3}\right)_{2}$ : Colson SF, Robinson SD, Robinson PD, Hinckley CC. Acta Cryst C 1989;45:715.

22. (a) Tadokoro M, Kanno H, Kitajima T, Shimada-Umemoto H, Nakanishi N, Isobe K, Nakasuji K. Proc Natl Acad Sci U S A 2002;99:4950. [PubMed: 11929979] (b) Mandon D, Ott-Woelfel F, Fischer J, Weiss R, Bill E, Trautwein AX. Inorg Chem 1990;29:2442. (c) Mayboroda A, Comba P, Pritzkow H, Rheinwald G, Lang H, van Koten G. Eur J Inorg Chem 2003:1703.

23. Jeffrey, GA. An Introduction to Hydrogen Bonding. Oxford University Press; New York: 1997.

24. Walstrom A, Pink M, Tsvetkov NP, Fan H, Ingleson M, Caulton KG. J Am Chem Soc 2005;127:16780. [PubMed: 16316212]supporting information

25. $\mathrm{CD}_{3} \mathrm{OD}$ is used in ${ }^{13} \mathrm{C}\left\{{ }^{1} \mathrm{H}\right\} \mathrm{NMR}$ instead of $\mathrm{CD}_{3} \mathrm{CN}$ because the latter solvent has a resonance at $\delta 118$ that significantly overlaps with the low intensity quartets of hfac- $\mathrm{CF}_{3}$.

26. (a) Kennedy DC, Wu A, Patrick BO, James BR. Inorg Chem 2005;44:6529. [PubMed: 16156610] (b) Belle C, Bougault C, Averbuch M-T, Durif A, Pierre J-L, Latour J-M, Le Pape L. J Am Chem Soc 2001;123:8053. [PubMed: 11506562] (c) Bertini I, Capozzi F, Luchinat C, Turano P. J Magn Reson 1991;95:244.

27. Izutsu, K. Acid-Base Dissociation Constants in Dipolar Aprotic Solvents. Blackwell Scientific; Boston: 1990.

28. Schwesinger R, Schlemper H. Angew Chem Int Ed Engl 1987;26:1167. 
29. Wu A, Mayer JM. to be submitted

30. Ghumaan S, Sarkar B, Patra S, Parimal K, van Slageren J, Fiedler J, Kaim W, Lahiri GK. J Chem Soc, Dalton Trans 2005:706.

31. Seddon, EA.; Seddon, KR. The Chemistry of Ruthenium. Elsevier; Amsterdam: 1984. p. 474

32. Ref. 7c: supporting information.

33. (a) Bandlish BK, Shine HJ. J Org Chem 1977;42:561. (b) Eberson L, Larsson B. Acta Chem Scand, Ser B 1986;40:210. (c) Rhile IJ, Markle TF, Nagao H, DiPasquale AG, Lam OP, Lockwood MA,

Rotter K, Mayer JM. J Am Chem Soc 2006;128:6075. [PubMed: 16669677]and references therein

34. Gould IR, Ege D, Moser JE, Farid S. J Am Chem Soc 1990;112:4290.

35. Mohammadpoor-Baltork I, Abdollahi-Alibeik M. Bull Korean Chem Soc 2003;24:1354.

36. Keene FR. Coord Chem Rev 1999;187:121.and references therein

37. (a)TilsetMBalzaniVElectron Transfer in ChemistryWiley-VCHWeinheim 20012677713 (b) Parker VD, Handoo KL, Roness F, Tilset M. J Am Chem Soc 1991;113:7493.(c) Ref. 37a gives $C_{G}=54.9$ $\mathrm{kcal} \mathrm{mol}^{-1}$ for cycles in $\mathrm{MeCN}$ with reduction potentials referenced to $\mathrm{Cp}_{2} \mathrm{Fe}^{+/ 0}$ (p. 681), while ref. $37 \mathrm{~b}$ gives $\mathrm{C}_{\mathrm{G}}=53.7 \mathrm{kcal} \mathrm{mol}^{-1}$ for cycles in $\mathrm{MeCN}$ with reduction potentials referenced to $\mathrm{H}^{+} /$ $\mathrm{H}_{2}$ in $\mathrm{MeCN}$.

38. Kolthoff IM, Chantooni MK Jr. J Phys Chem 1972;76:2024.

39. Weast, RC., editor. CRC Handbook of Chemistry and Physics. 67. CRC Press; Boca Raton, FL: 19861987. p. D-69

40. Brunner E. J Chem Eng Data 1985;30:269.

41. The estimated error in the BDFE is predominantly from the uncertainty in $C_{\mathrm{G}}$, which we estimate to be $\pm 1 \mathrm{kcal} \mathrm{mol}^{-1.37}$

42. The relative error in $\Delta G^{\circ}$ calculated from the difference between two BDFEs (determined with the same $C_{\mathrm{G}}$ ) is less than the error of each BDFE because the uncertainty in $C_{\mathrm{G}}$ cancels itself out.

43. Gas-phase thermochemical data from NIST Chemistry Webbook, June 2005 Release.

44. This analysis follows that in Soper, Rhile IJJD, DiPasquale AG, Mayer JM. Polyhedron 2004;23:323. and references therein

45. Examples of isolated hydrogen atom abstractors $\left(\mathrm{X}^{\bullet}\right)$ with relative high $\mathrm{X}-\mathrm{H}$ BDEs (ignoring entropy differences between $\mathrm{X}$ and $\mathrm{HX}, \mathrm{BDFE}(\mathrm{X}-\mathrm{H}) \cong \mathrm{BDE}(\mathrm{X}-\mathrm{H})-5 \mathrm{kcal} \mathrm{mol}^{-1}$ in organic solvents $\left.{ }^{7 \mathrm{~b}}\right)$ : (a) $\left[\mathrm{Fe}^{\mathrm{III}}(\mathrm{PY} 5)(\mathrm{OMe})\right]^{2+}$ (PY5 = 2,6-bis(bis(2-pyridyl)methoxymethane)-pyridine), $\mathrm{BDE}=83.5$ $\mathrm{kcal} \mathrm{mol}^{-1}$ in MeOH: Goldsmith CR, Jonas RT, Stack TDP. J Am Chem Soc 2002;124:83. [PubMed: 11772065](b) $\left[\mathrm{Mn}^{\mathrm{III}}(\mathrm{PY} 5)(\mathrm{OH})\right]^{2+}, \mathrm{BDE}=82 \mathrm{kcal} \mathrm{mol}^{-1}$ in MeCN: Goldsmith CR, Cole AP, Stack TDP. J Am Chem Soc 2005; 127:9904. [PubMed: 15998097](c) [ $\left.\mathrm{Mn}^{\mathrm{III}}\left(\mathrm{H}_{3} 1\right) \mathrm{O}\right]^{2-}\left(\mathrm{H}_{3} 1=\right.$ tris[(N'tert-butylureaylato)-N-ethyl) $]$ aminato $), \mathrm{BDE}=77 \mathrm{kcal} \mathrm{mol}^{-1}$ in DMSO $\left(\left[\mathrm{Mn}^{\mathrm{IV}}\left(\mathrm{H}_{3} 1\right) \mathrm{O}\right]^{2-}\right.$ and $\left[\mathrm{Fe}^{\mathrm{IV}}\left(\mathrm{H}_{3} 1\right) \mathrm{O}\right]^{2-}$, BDEs $=110$ and $115 \mathrm{kcal} \mathrm{mol}^{-1}$, were not isolated.): Gupta R, Borovik AS. J Am Chem Soc 2003;125:13234. [PubMed: 14570499](d) [Ru $\left.{ }^{\mathrm{IV}}(\mathrm{bpy})_{2}(\mathrm{py}) \mathrm{O}\right]^{2+}, \mathrm{BDE}=84 \mathrm{kcal} \mathrm{mol}^{-1}$ in MeCN: ref. 1e and Bryant JR, Mayer JM. J Am Chem Soc 2003;125:10351. [PubMed: 12926960] (e) $\mathrm{Mn}{ }^{\mathrm{VII}} \mathrm{O}_{4}{ }^{-}, \mathrm{BDE}=80 \mathrm{kcal} \mathrm{mol}^{-1}$ in $\mathrm{H}_{2} \mathrm{O} ;\left[\mathrm{Mn}_{2}(\mu-\mathrm{O})_{2}(\text { phen })_{4}\right]^{3+}$ (phen = 1,10-phenanthroline),

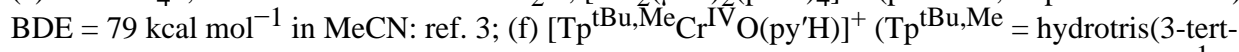
butyl-5-methylpyrazolyl)borate, py'H = 3-tert-butyl-5-methylpyrazole), $\mathrm{BDE}>75.3 \mathrm{kcal} \mathrm{mol}^{-1}$ in $\mathrm{CD}_{2} \mathrm{Cl}_{2}$ : Qin, K.; Incarvito, C. D.; Rheingold, A. L.; Theopold, K. H. J. Am. Chem. Soc. 2002, 124, 14008; (g) $\left[\mathrm{Fe}^{\mathrm{IV}}(\mathrm{O})(\mathrm{N} 4 \mathrm{Py})\right]^{2+}$ and $\left[\mathrm{Fe}^{\mathrm{IV}}(\mathrm{O})(\mathrm{Bn}-\mathrm{tpen})\right]^{2+}(\mathrm{N} 4 \mathrm{Py}=\mathrm{N}, \mathrm{N}-$ bis (2-pyridylmethyl)-N-bis (2-pyridyl)methylamine, Bn-tpen = N-benzyl-N, $\mathrm{N}^{\prime}, \mathrm{N}^{\prime}$-tris(2-pyridylmethyl)ethylenediamine) oxidize $\mathrm{C}-\mathrm{H}$ bonds of cyclohexane $\left(\mathrm{BDE} \approx 99.3 \mathrm{kcal} \mathrm{mol}^{-1}\right)$ in MeCN: Kaizer, J.; Klinker, E. J.; Oh, N. Y.; Rohde, J.-U.; Song, W. J.; Stubna, A.; Kim, J.; Münck, E.; Nam, W.; Que, L., Jr.; (h) tritert-butylphenoxyl radical, BDE $=82.3 \mathrm{kcal} \mathrm{mol}^{-1}$ in DMSO: Bordwell FG, Liu WZ. J Am Chem Soc 1996;118:10819.

46. The $\Delta E_{1 / 2}(0.99 \mathrm{~V})$ reported here is calculated from $E_{1 / 2}$ values of $c i s$ - $\left[\mathrm{Ru}(\mathrm{acac})_{2}(\mathrm{MeCN})_{2}\right]^{+/ 0}$ and cis- $\left[\mathrm{Ru}(\mathrm{hfac})_{2}(\mathrm{MeCN})_{2}\right]^{+/ 0}\left(-0.29 \mathrm{~V}\right.$ and $0.70 \mathrm{~V}$ vs. $\left.\mathrm{Cp}_{2} \mathrm{Fe}^{+/ 0}\right)$ measured in this work, which agree very well with those predicted by Lever parameters $(-0.28$ and $0.69 \mathrm{~V}),{ }^{47}$ but differ significantly than those reported in ref. $15\left(\Delta E_{1 / 2}=1.22 \mathrm{~V}\right)$.

47. Lever ABP. Inorg Chem 1990;29:1271.

48. Pratt DA, DiLabio GA, Mulder P, Ingold KU. Acc Chem Res 2004;37:334. [PubMed: 15147174] 
49. (a) Raebiger JW, Miedaner A, Curtis CJ, Miller SM, Anderson OP, DuBois DL. J Am Chem Soc 2004;126:5502. [PubMed: 15113222] (b) Fraze K, Wilson AD, Appel AM, Rakowski DuBois M, DuBois DL. Organometallics 2007;26:3918-3924.

50. Armarego, WLF.; Chai, CLL. Purification of Laboratory Chemicals. 5. Butterworth-Heinemann; Amsterdam: 2003.

51. Otwinowski, Z.; Minor, W. Methods in Enzymology. Carter, CW., Jr; Sweet, RM., editors. 276. Academic Press; New York: 1997. p. 307-326.

52. Altomare A, Cascarano G, Giacovazzo C, Guagliardi A, Burla MC, Polidori G, Camalli M. J Appl Cryst 1994;27:435.

53. Sheldrick, GM. SHELXL-97: Program for the Refinement of Crystal Structures. University of Göttingen; Göttingen, Germany: 1997. 
(a)

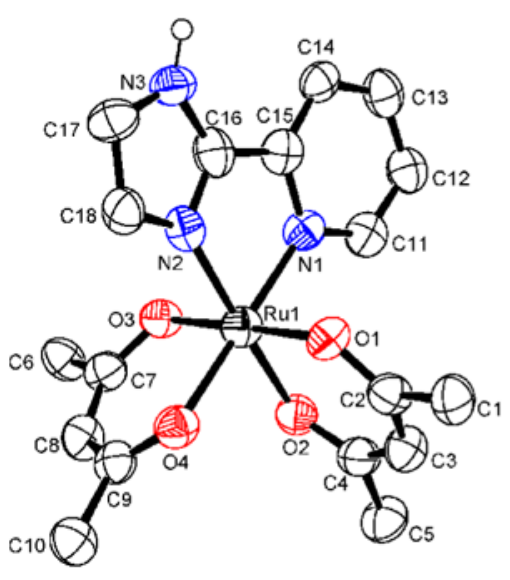

(b)

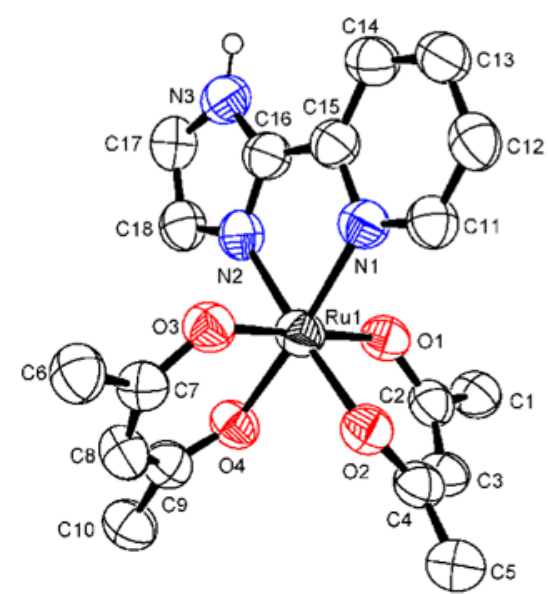

(c)

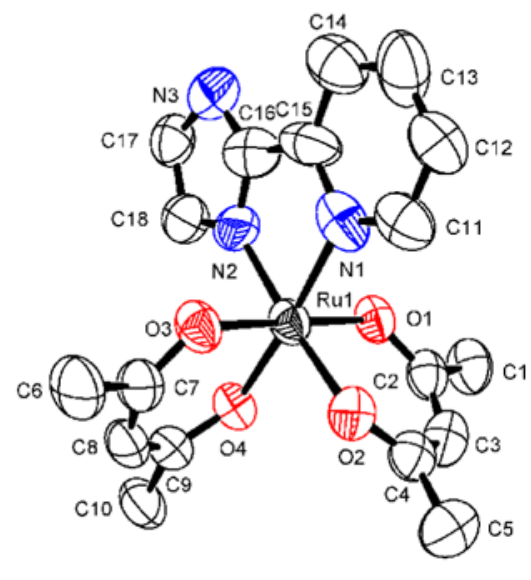

Figure 1.

ORTEP drawings of (a) $\mathrm{Ru}^{\mathrm{II}}(\text { acac })_{2}\left(\right.$ py-imH) (1), (b) $\left[\mathrm{Ru}^{\mathrm{III}}(\mathrm{acac})_{2}(\mathrm{py}-\mathrm{imH})\right]^{+}(\mathbf{2})$, and (c) $\mathrm{Ru}^{\mathrm{III}}(\text { acac })_{2}$ (py-im) (3). Hydrogen atoms are omitted for clarity except for the $\mathrm{N}-\mathrm{H}$ atom. 
(a)

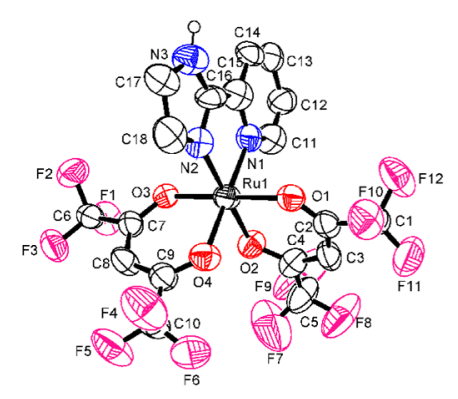

(b)

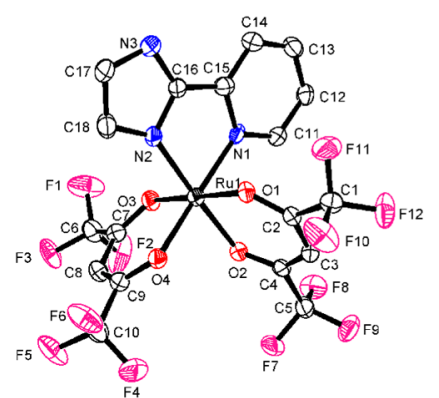

(c)

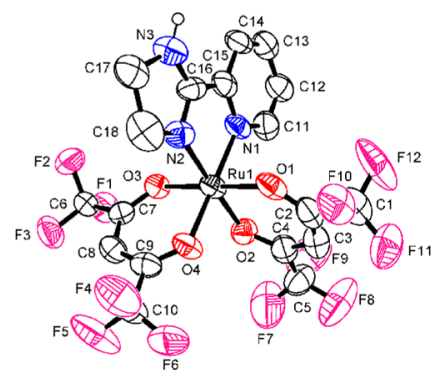

Figure 2.

ORTEP drawings of (a) $\mathrm{Ru}^{\mathrm{II}}(\mathrm{hfac})_{2}(\mathrm{py}-\mathrm{imH})(\mathbf{4})$, (b) $\left[\mathrm{Ru}^{\mathrm{II}}(\mathrm{hfac})_{2}(\mathrm{py}-\mathrm{im})\right]^{-}$(5), and (c) $\mathrm{Ru}^{\mathrm{II}}(\mathrm{hfac})_{2}$ (py-imnH) (8) [see below], showing one of the two independent molecules in the unit cell for each of $\mathbf{4}$ and $\mathbf{8}$. Hydrogen atoms are omitted for clarity except for the $\mathrm{N}-\mathrm{H}$ atom. 
(a)

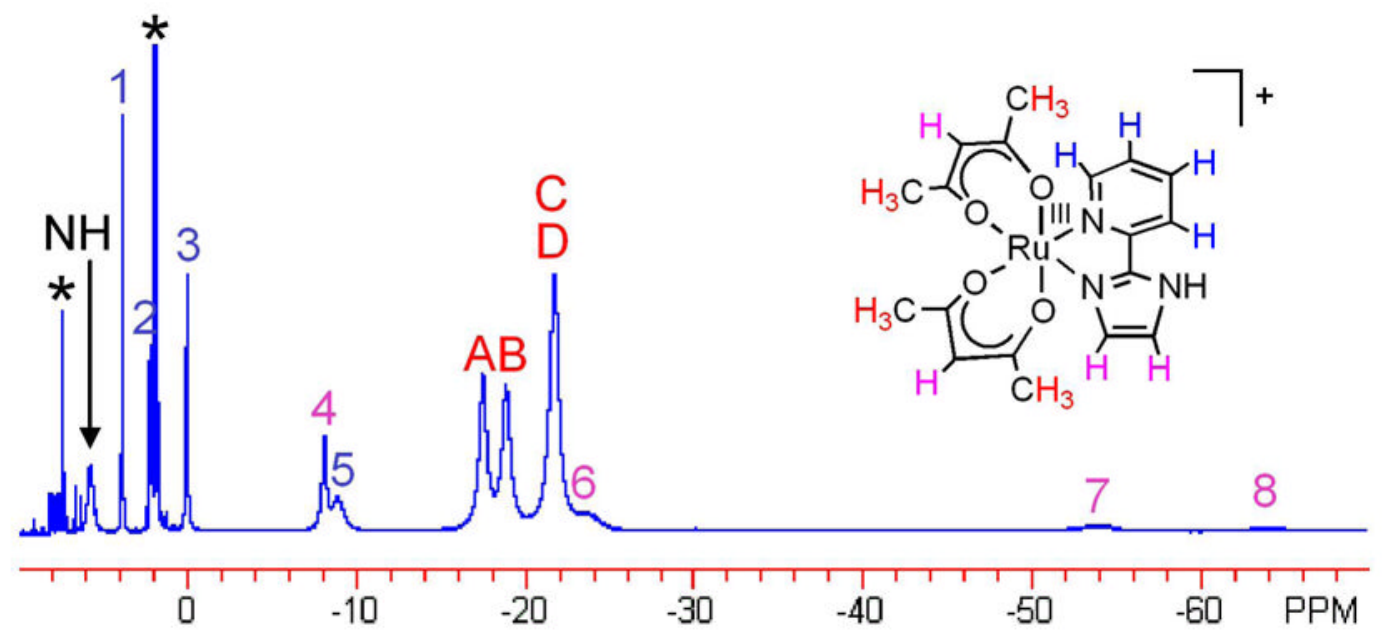

(b)

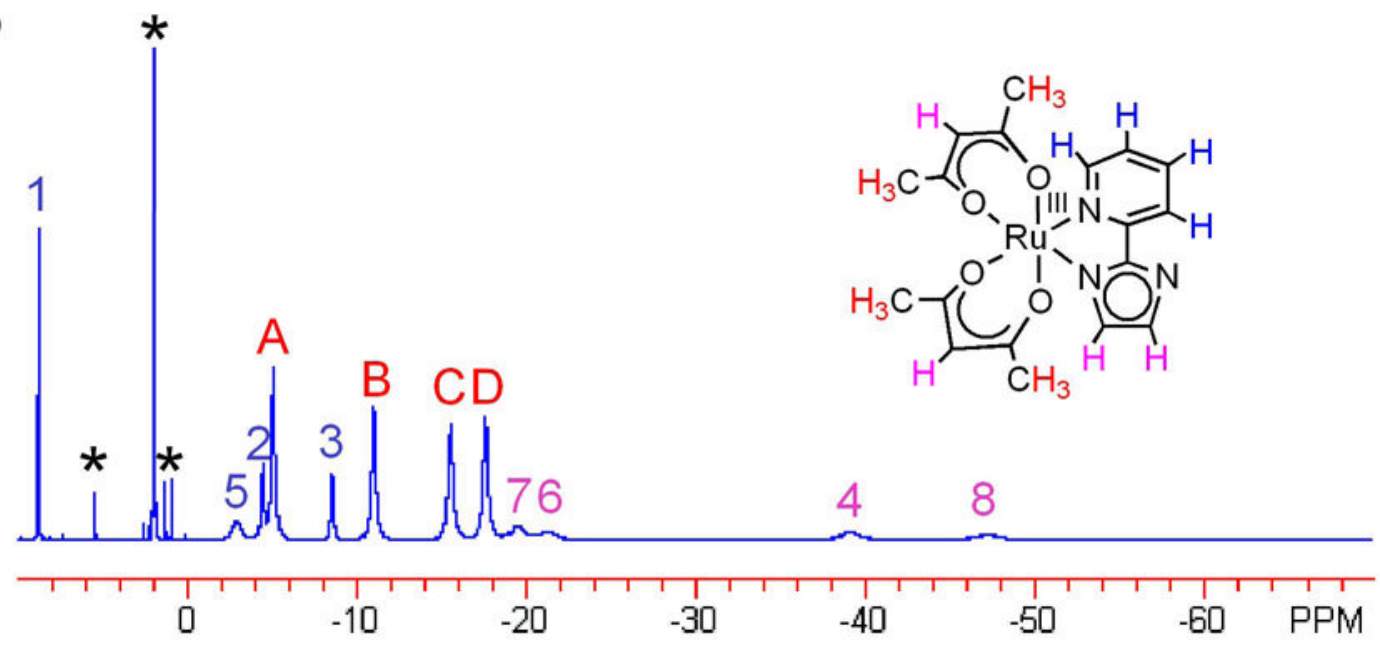

Figure 3.

${ }^{1} \mathrm{H}$ NMR spectra of (a) $\left[\mathrm{Ru}^{\mathrm{III}}(\mathrm{acac})_{2}(\mathrm{py}-\mathrm{imH})\right] \mathrm{OTf}(\mathbf{2})$ and (b) $\mathrm{Ru}^{\mathrm{III}}(\mathrm{acac})_{2}(\mathrm{py}-\mathrm{im})(\mathbf{3})$ in $\mathrm{CD}_{3} \mathrm{CN}$. Peaks $\mathrm{A}$ to $\mathrm{D}$ are assigned as acac- $\mathrm{CH}_{3}$ protons, peaks $1,2,3$, and 5 as pyridine protons, and 4, 6, 7, and 8 as acac- or imidazole- $\mathrm{CH}$ protons. The letters and numbers show the corresponding signals between $\mathbf{2}$ and $\mathbf{3}$, as determined by reversible NMR titration by DBU/ HOTf. Solvent and impurity peaks are denoted by asterisks (*). 


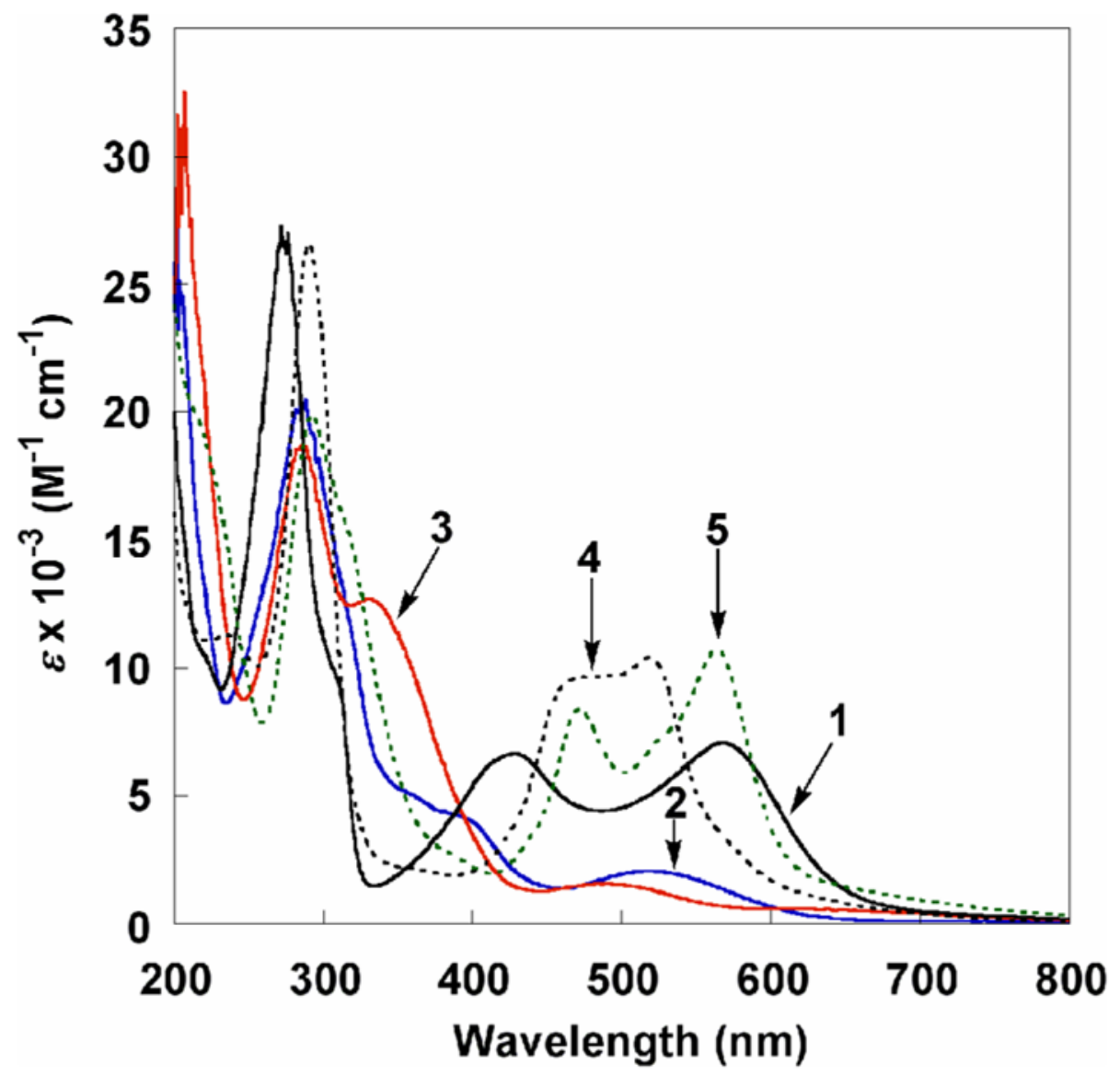

Figure 4.

UV-vis spectra of Ru${ }^{\mathrm{II}}(\mathrm{acac})_{2}\left(\right.$ py-imH) (1), $\left[\mathrm{Ru}^{\mathrm{III}}(\mathrm{acac})_{2}(\right.$ py-imH) $)$ OTf (2), $\mathrm{Ru}^{\mathrm{III}}(\mathrm{acac})_{2}$ (pyim) (3), $\mathrm{Ru}^{\mathrm{II}}(\mathrm{hfac})_{2}(\mathrm{py}-\mathrm{imH})(\mathbf{4})$, and $[\mathrm{DBU}-\mathrm{H}]\left[\mathrm{Ru}^{\mathrm{II}}(\mathrm{hfac})_{2}(\mathrm{py}-\mathrm{im})\right](\mathbf{5})$ in $\mathrm{MeCN}$. 


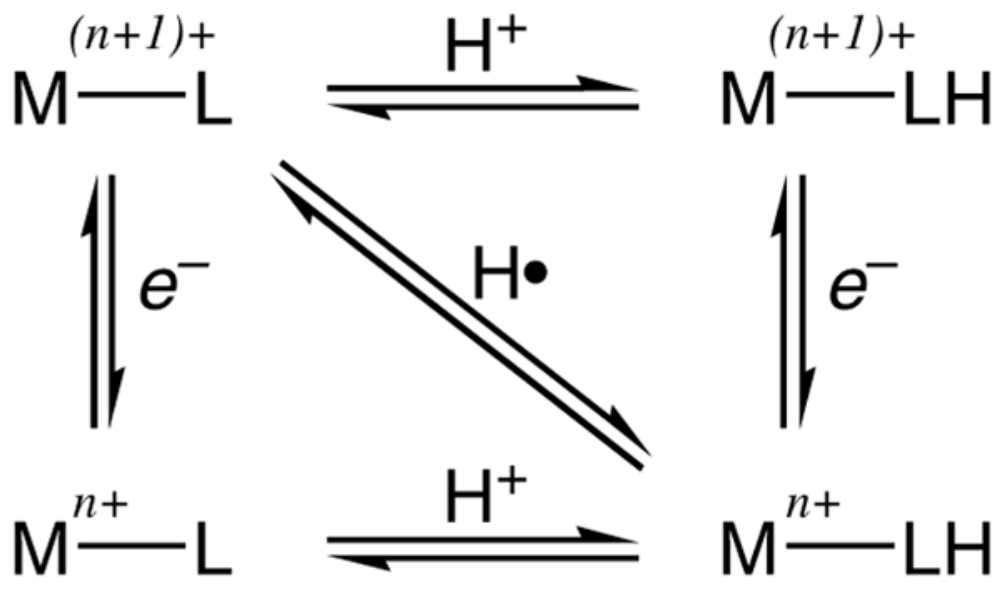

Scheme 1.

Square Scheme for Hydrogen Atom Transfer 
(a)
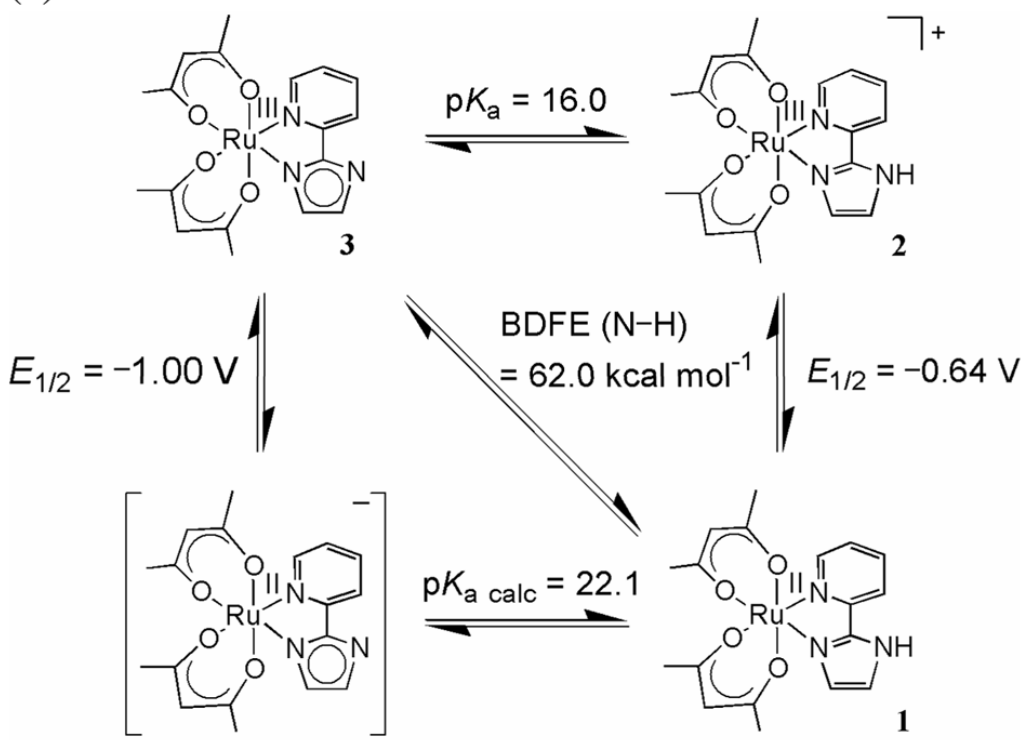

(b)

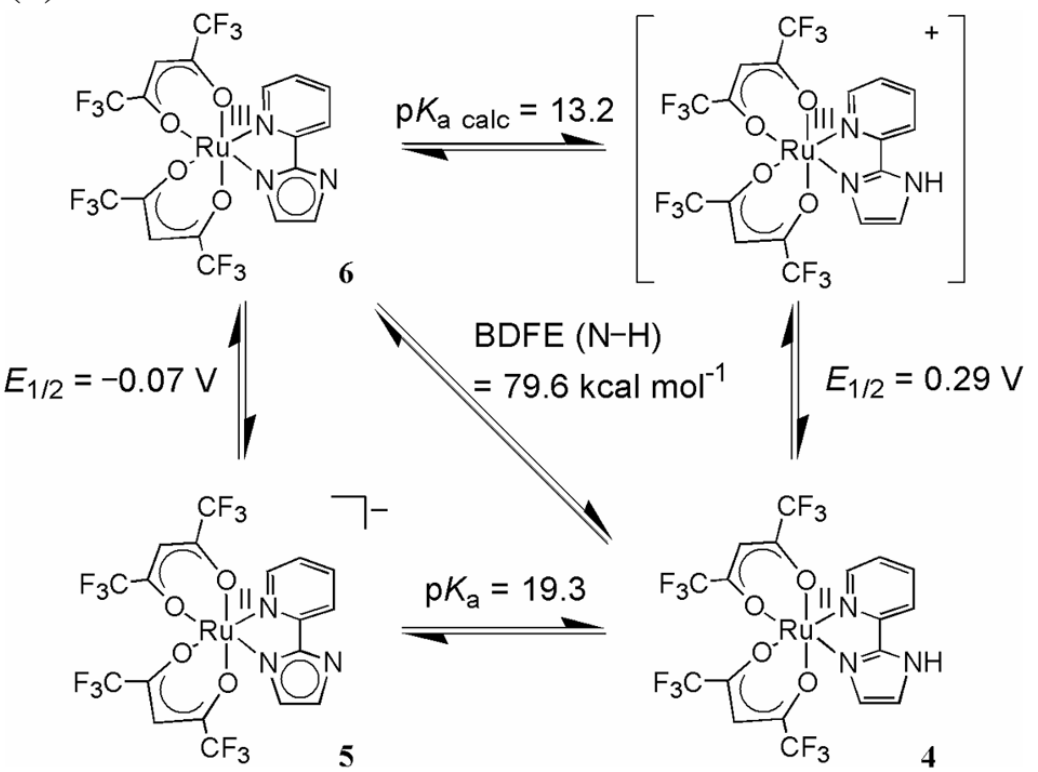

Scheme 2.

Square schemes for (a) the Ru-acac-py-imH (1-3) and (b) the Ru-hfac-py-imH (4-6) systems (in $\mathrm{MeCN}$ at $298 \mathrm{~K}, E_{1 / 2}$ values $v$ s. $\mathrm{Cp}_{2} \mathrm{Fe}^{+/ 0}$ ). 


$$
\begin{aligned}
& \mathrm{Ru}^{\mathrm{II}}(\mathrm{acac})_{2}(\mathrm{py}-\mathrm{imH})(\mathbf{1}) \rightarrow \mathrm{Ru}^{\mathrm{III}}(\mathrm{acac})_{2}(\text { py-im })(\mathbf{3})+\mathrm{H}^{\bullet} \quad \Delta G^{\circ}=62 \mathrm{kcal} \mathrm{mol}^{-1} \\
& 1 / 4 \mathrm{O}_{2}+\mathrm{H}^{\bullet} \rightarrow 1 / 2 \mathrm{H}_{2} \mathrm{O} \quad \Delta G^{\circ} \sim-80 \mathrm{kcal} \mathrm{mol}^{-1} \\
& \mathbf{1}+1 / 4 \mathrm{O}_{2} \rightarrow \mathbf{3}+1 / 2 \mathrm{H}_{2} \mathrm{O} \quad \Delta G^{\circ} \sim-18 \mathrm{kcal} \mathrm{mol}^{-1}
\end{aligned}
$$

Scheme 3. 


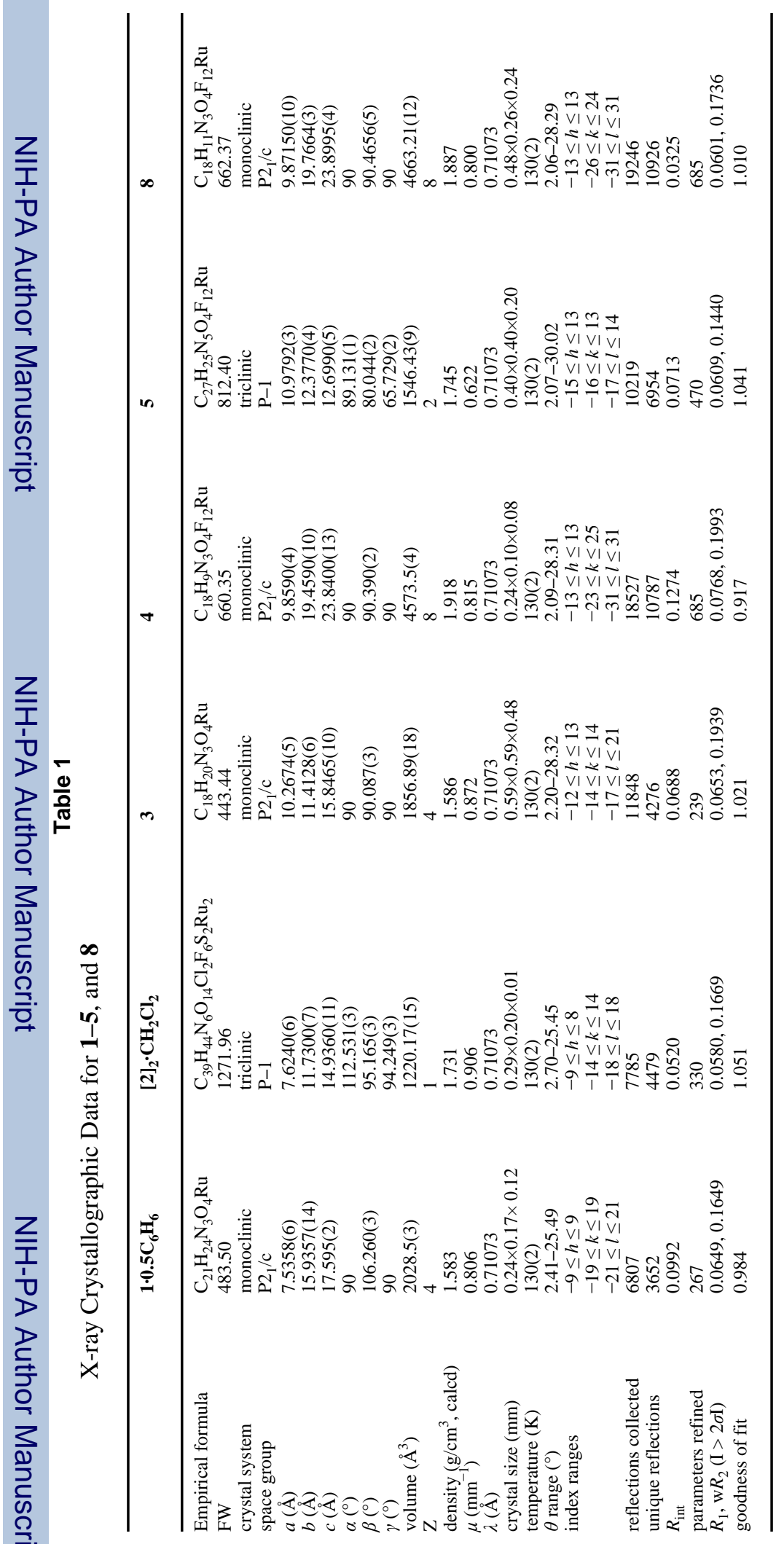


